\title{
VI Appendices
}

\section{Appendix A: The Hebrew Original of the Parable of the Pearl}

In this appendix, I would like to offer a critical edition of the Hebrew original of the entire chapter that serves as the basis of most of the discussions in the second part of this study; I shall then translate and analyse the last part of this chapter, paragraph [d], as part of the thematic approach I have delineated above. Or ha-Śekhel is one of Abulafia's most popular books and it is extant in approximately thirty manuscripts. I have chosen four manuscripts in order to check the variants that may have an impact on the meaning of the given passages. These manuscripts were copied between the fourteenth and sixteenth centuries, constituting some of the earliest manuscripts of the book, while the base manuscript, Ms. Firenze-Medicea Laurenziana Plut II. 20/1, is a very legible fifteenth-century codex, whose version was compared to another, unidentified manuscript with the variants being marked in the margin. The printed version on pages 33-36 of Amnon Gross's edition does not mention from which manuscript it was printed, but it is most probably Ms. Fulda, Oct. Ba 2.

$$
\begin{aligned}
& \text { גוף הטקסט על פי כתב יד פירנצה-לאורנציאנה PLUT. II.20/1 דף 17א-11 }
\end{aligned}
$$

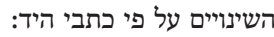

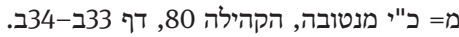

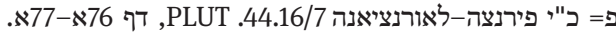

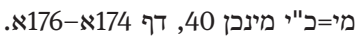

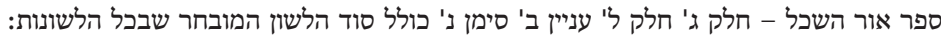

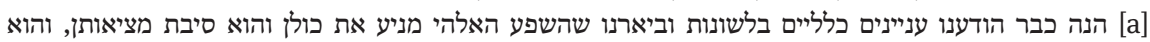

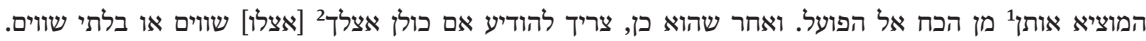

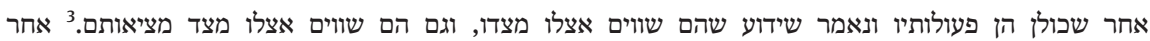

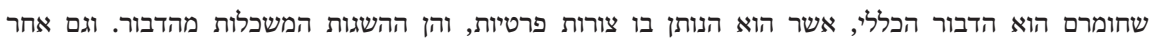

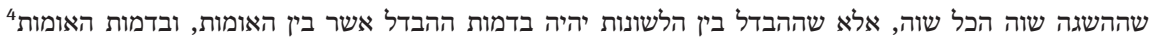

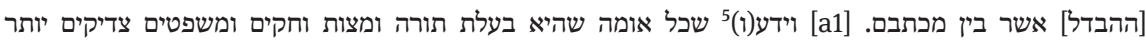

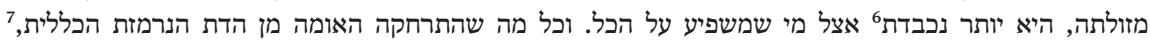

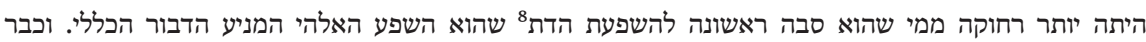

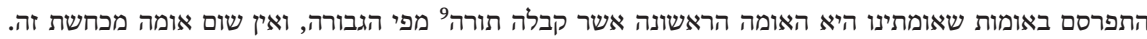

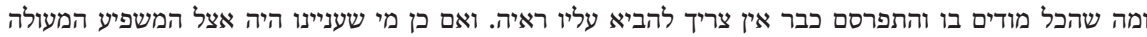

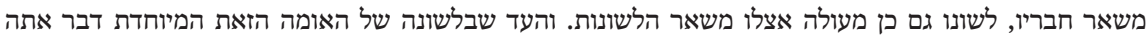

פ: במקום המוציא אותן-'המוציאן' 1

מ, פ, מי: אצלו 2

על ההבחנה בין ״מצד“ האל ומצדנו ראו לעיל פרק 16 הערה 128 ופרק 17 הערה מי: מל מיל 3

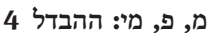

מ, פ, מי: וידוע 5

מ, פ, מי: נכבדת יותר פירות 6

מ, פ, מי: הכללית הנרמזת מדת מרת 7

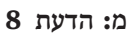

מ: ליתא 'תורה'

¿ OpenAccess. (c) 2020, Moshe Idel, published by De Gruyter. (cc))BY-NC-ND This work is licensed under the Creative Commons Attribution-NonCommercial-NoDerivatives 4.0 License.

https://doi.org/10.1515/9783110599978-006 


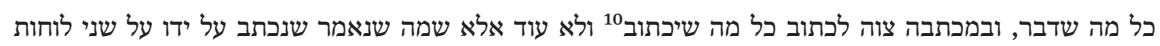

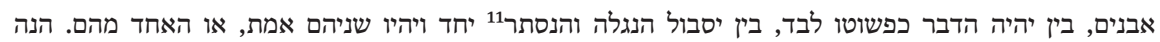

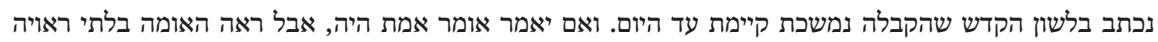

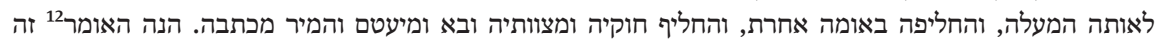

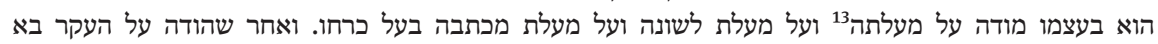

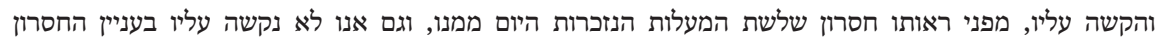

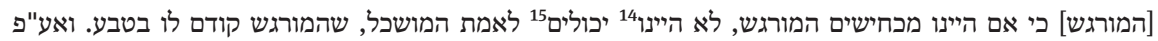

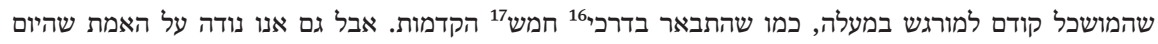

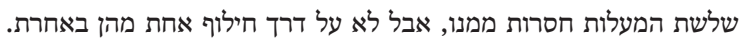

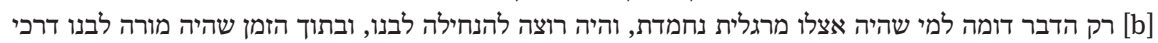

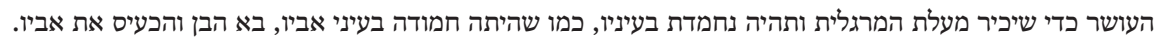

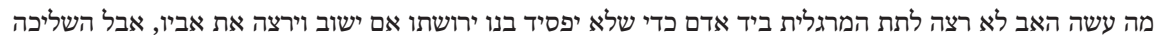

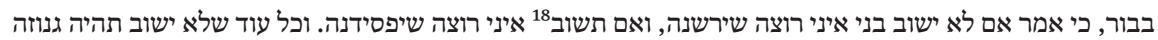

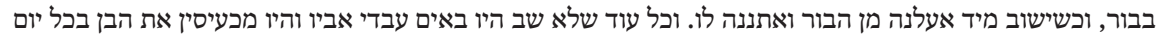

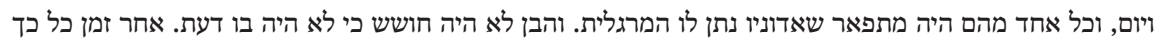

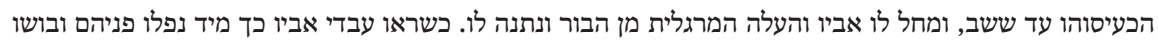

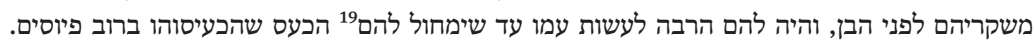

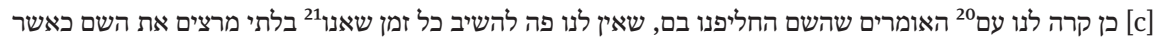

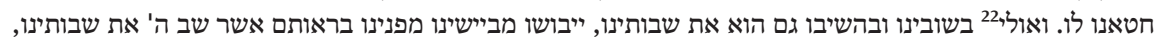

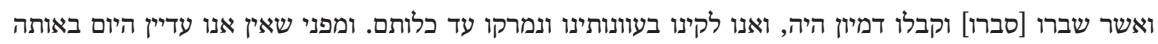

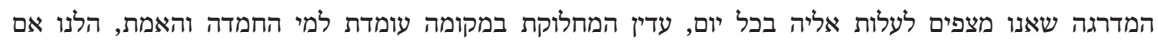

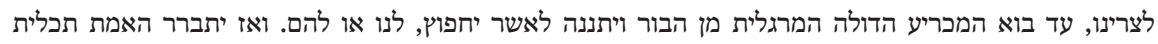

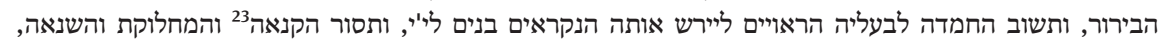

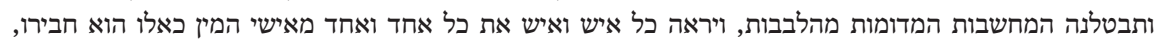

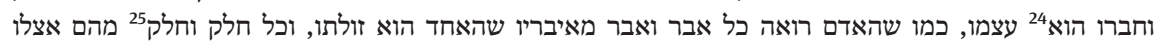

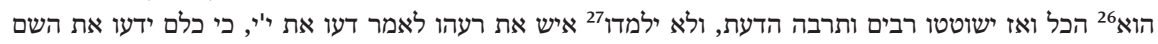

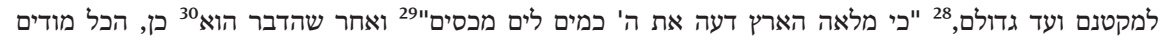

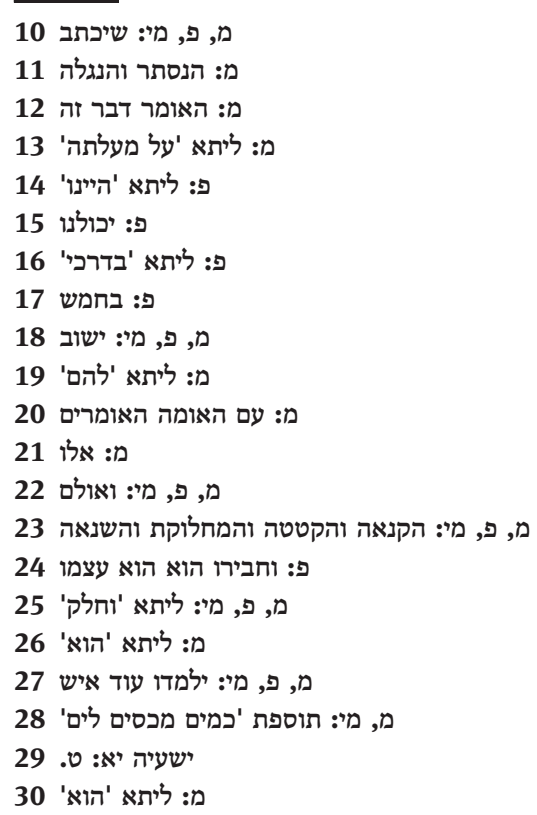


שמבחר כל הלשונות מאז הוא לשון הקדש. ועל כן נודע מה שנודע בה לנביאים בסוד השם המפורש, מה שלא נודע

לזולתם מאישי מין האל האדם.

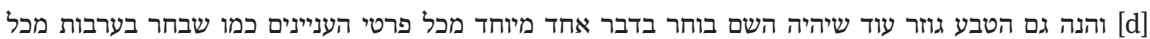

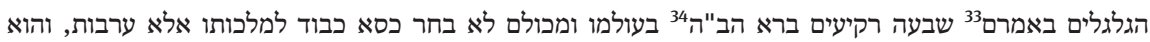

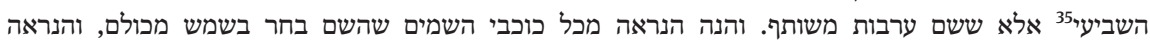

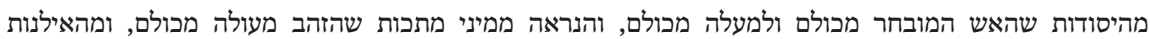

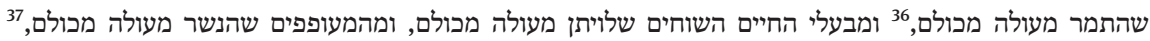

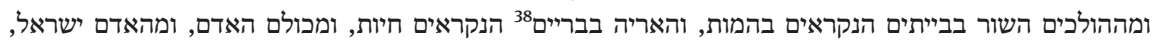

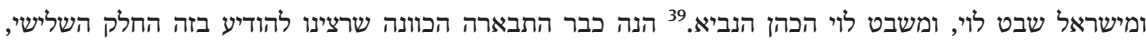
שמבחר השלישי40 [הלשונות] היא לשון הקדש.

So far, most of the original text of the parable has been translated and analysed above, with the exception of paragraph [d]. Let me now translate this paragraph and analyse some of its conceptual components:

[d] And nature also determines that God will choose a certain special thing from all the details of matters, as He chose 'Aravot from all the spheres, as they said"1 "the Holy One, blessed be He, created seven firmaments in His world and He chose only 'Aravot as His Seat of Glory for His kingship" and it is the seventh, ${ }^{42}$ but the term 'Aravot is an equivocal name (homonym). And behold that among all the stars of the world, He chose the sun out of all of them, and behold that among the elements, fire is the chosen one, and it is higher than all, and behold that among all the kinds of metals, gold is the chosen one, and among the trees, the palm tree is the best of all, and among the animals that swim, the Leviathan is the best, and among the flying ones, the eagle is the best, and among the domestic animals that walk, the ox is the best, and among the wild ones, called the beasts, the lion [is the best], and among all [the animals], man, ${ }^{43}$ and among [all] men, the Israelites, and among the Israelites, the tribe of Levi [is the best], and

\footnotetext{
פ: המין 31

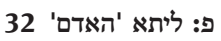

ראו להלן הערה 32.

מ, פ: הקב"ה 34

מ: תוספת 'או אמור התשיעי' 35 בעיה

פ: ומהאילנות שהתמר מעלה בכלם-תוספת בשולי הגיליון 36

מ: ליתא 'והמעופפים שהנשר מעולה מכולם' 37 בהתים 36

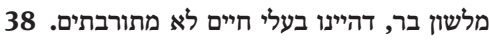

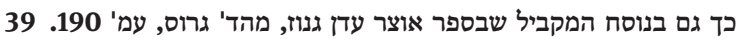

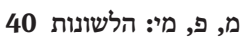

41 This statement is quoted verbatim in the parallel discussion in Oșar 'Eden Ganuz, 1:10, 185, and in a very similar version in Mafteah ha-Ra'ayon, in chapter 18 note 168 above. I have not found this precise formulation in the available treatises in late antique or early medieval Jewish texts. I nevertheless assume that this is an authentic quote. The whole issue deserves a separate investigation. See, for example, a partial parallel found in the sixteenth-century Kabbalist Rabbi Judah Hallewah's Sefer Șafnat Pa'aneah, Ms. Dublin, Trinity College, B. 5. 27, fol. 15a. Ḥallewah was not influenced by Abulafia's writings.

42 The assumption that the seventh is the best is found in late antique Jewish sources, e.g., the book of Enoch.

43 The last four beings indubitably reflect the four beasts in the vision of the chariot in Ezekiel 1. However, Abulafia refrains from mentioning the chariot or the merkavah in this chapter, just as he does not mention other biblical matters, as pointed out above. 
among the tribe of Levi, the priest [who is] a prophet [is the best]. Behold, the intention that we wanted to announce in this third part ${ }^{44}$ has been clarified to the effect that the best of the languages is the Holy Language. ${ }^{45}$

Let us first turn to the opening sentence: according to Abulafia, nature was conceived as determining what God will choose; namely, something that is better than all other things. This is quite a strange formulation that, in my opinion, means that nature is the dominant force. It actually precludes the possibility of divine choice, or in any case free choice, as we discussed at length in chapter 18 above. It also hints at nature having some sort of antecedence to the divine choice.

Another important element found in this passage is the occurrence of equivocality in connection to the term 'Aravot, ${ }^{46}$ which means there are two or more divergent meanings, probably referring to the fact that an act of choice made by an entity that has a free will is not necessarily related to what may be seen in nature, but rather something quite different: a hierarchy which is natural, but also arbitrary. What such an allegorical understanding may be can be learnt from the opening verses of a poem in one of Abulafia's epistles, where it is written that "two tablets of stones are written, combined [of letters] on the heart of the sphere ${ }^{47}$ of 'Aravot. Designed in the form of cherubs, ${ }^{48}$ the Rock $^{49}$ prepared them in order to answer their ques-

44 Of his Sefer Or ha-Śekhel.

45 Compare to a parallel discussion in "Ševa' Netivot ha-Torah," 16-17, translated in Idel, Language, Torah, and Hermeneutics, 12-13.

46 The term for a high sphere occurs several times in Maimonides, Guide 1:70. Enigmatic references to the secret of 'Aravot can be found in Abulafia's teacher Rabbi Baruch Togarmi's Commentary on Sefer Yeșirah, printed in Scholem, The Kabbalah of Sefer ha-Temunah, 236, 238. See also Abulafia's Sefer Ge'ulah, 14, and the untitled treatise found in Ms. Firenze, Laurenziana, Plut. II 48, fol. 99a. In Rabbi Nathan ben Sa'adyah's Ša'arei Ședeq, 'Aravot is interpreted as referring to the universal soul as part of his more Neo-Platonic propensity, a turn that perhaps began in Abulafia's late work. See his Le Porte della Giustizia, 469, 474. For Abulafia's resort to the term "supernal soul" as a cosmic soul, see Hayyei ha-Nefeš, 87.

47 Galgal means, in an astronomical context, "a sphere or orb," especially when it is conjugated with 'Aravot. However, in Hebrew, it also means "circle," and this is its meaning here when interpreted in the manner in which I propose it was interpreted by Abulafia. See also the passage quoted from Or ha-Śekhel, 31, above.

48 I wonder whether the two cherubs refer here to the faculties of the imagination and the intellect. Compare also to Abulafia's Untitled Treatise preserved in Ms. Firenze, Laurenziana, Plut. II, 48, fol. 99a, where there is a link between the term 'Aravot and the cherubs in the context of describing some form of supernal Paradise or Pardes. The various interpretations of this word in Abulafia's writings are an example of exegetical fluidity, or of what I propose to call the grapefruit approach; namely, the existence of a variety of interpretations on a concept or theme that is important for a certain thinker. According to such a view, what is more important is the topic that is repeatedly interpreted and not the specifics of each of these interpretations. See Idel, Ben, 616-18.

49 Compare the link between the term "rock" (referring to God), writing, and the heart in the poem written by Abulafia mentioned in chapter 10 note 153 above: התוה צור על לב איש תו "The Rock has put a sign on the man's heart"). This is a comment on Ezekiel 9:4; compare also to the discussions in Abulafia's Sefer ha-Ot, 82-83, concerning the sign on the forehead, as well as to Or ha-Śekhel, 76. 
tions." ${ }^{50}$ The tablets of stone being an allegory for the human faculties was discussed in chapter 16 above. My assumption is that the firmament of 'Aravot -imagined in many other cases in the Middle Ages and in Abulafia's early writings as the ninth of the ten spheres ${ }^{51}$-is understood here as referring to some form of mixture through the resort to the meaning of the root ' $R B$, which means "to combine" or "to mix." In this context, he is alluding to the practice of combining letters by means of concentric circles. ${ }^{52}$ Moreover, the end of the word 'Aravot, Ot, has been understood as if it refers to the word $O t$, probably a reference to "letter."

This image of a sphere moving and thus combining letters is widespread in Abulafia's writings. ${ }^{53}$ Indeed, the understanding of the term 'Aravot as referring to a certain mode of combining letters is quite explicit in a large fragment from an untitled work by Abulafia, where the ecstatic Kabbalist writes: "The comprehension of the divine name is [found] ${ }^{54}$ in 'Aravot, and it is known that 'Aravot is a noun referring to the mixture and the combination of the amalgam, and it also refers to their mixture and their amalgamation with one another, and so is the combination of letters." 55 This passage fits Abulafia's recurrent claim that it is impossible to know the divine name except by resorting to the combination of letters. ${ }^{56}$ In my translation, I resorted to metallurgical terms stemming from the root $R B$, which is perhaps a hint at alchemy, against the plain sense that refers to another, much more important act: the combination of letters. ${ }^{57}$ It should be noted that our interpretation of the root ' $R B$ as referring to a practice belonging to ars combinatoria is found in quite an ex-

50 Mașref la-Kesef, Ms. Sassoon 56, fol. 24b (now New York Public Library 190), printed in David S. Sassoon, אהל דוד: Sassoon Hebrew and Samaritan MSS (London: Oxford University Press, 1932), 424: מצורפים בלב גלגל ערבות - שני לוחות אבנים הם כתובים/ משורים הכינם צור להשיבם תשובות - מצוירים בצורת הכר שלים]בים.

51 See Geț ha-Šemot, 21.

52 See Idel, "Ramon Lull and Ecstatic Kabbalah," 170-74; Idel, "Sefer Yetzirah and Its Commentaries," 525-26; Harvey J. Hames, The Art of Conversion: Christianity and Kabbalah in the Thirteenth Century (Leiden: Brill, 2000), 118-41; and Adam Afterman, The Intention of Prayers in Early Ecstatic Kabbalah: A Study and Critical Edition of an Anonymous Commentary to the Prayers [Hebrew] (Los Angeles: Cherub Press, 2004), 35-64.

53 See Idel, Language, Torah, and Hermeneutics, 38-41.

54 Or "by means of."

55 See Ms. Firenze, Laurenziana, Plut. II, 48, fol. 78b:

כי השגת השם המפורש הוא בערבות וידוע כי ערבות הוא שם מורה על עירוב ותערובת הרכבה מורה על עירובם ועל הרכבם זו עם זו וכן צירוף האותיות.

See also my "Sefer Yeșirah and Its Commentaries," 534-35. On other meanings of the term 'Aravot, see also the passage in Ms. Firenze, Laurenziana, Plut. II, 48, fol. 95b.

56 See Sitrei Torah, 161.

57 It should be pointed out that the most common term for combinations of letters, șeruf, was sometimes related to the root $S R F$ that in some cases was interpreted as being related to purification or refining in alchemy. See Raphael Patai, The Jewish Alchemists: A History and Source Book (Princeton: Princeton University Press, 1994), 159. 
plicit manner in a book by Abulafia himself, ${ }^{58}$ indubitably inspired by the biblical verse where 'Aravot, referring to some form of clouds, occurs together with the divine name Yah. ${ }^{59}$ This is also the case in an early version of Rabbi Joseph Gikatilla's text Ša'ar ha-Niqqud. Abulafia considered Gikatilla to be the most successful Kabbalist as he claims in the passage that is mentioned in chapter 5 above. ${ }^{60}$

To return to the content of the poem: when combined with each of the other letters, the answers to the questions posed by the aspiring prophet, as in the case of the biblical Urim and Tumim, as they were understood by Abulafia, are part of the prophetic experience. ${ }^{61}$ This is but another allegorical-psychological understanding of the tablets of stone, in addition to that which we saw in chapter 16 above. The occurrence of the term "heart" in the above passage points to this transfer of the discussion from the astronomical context to the anthropological one. Moreover, the view that there is a divine throne-namely, the Seat of Glory-should, in many cases in Abulafia's thought, be understood as an allegory for the human intellectual faculties; $^{62}$ that is, as part of his more general proclivity towards spiritual allegoresis.

Thus, the traditional and quite concrete terms discussed in section [d], namely, the firmament of 'Aravot and the Seat of Glory (Kisse' ha-Kavod) as found in a yet unaccounted-for ancient dictum-the seat is understood in several instances in Abulafia's writings as the "nature of the heart" by dint of its shared numerical value ${ }^{63}-$ turn into references to the two major aspects of his Kabbalah: combinations of letters and some form of initial inwardness that is conducive to the union of extra-human intellectual entities. This specific kind of resort to the method of gematria is far removed from the manner in which other authors, mainly the Ashkenazi ones, used this method (as a way to find correspondences between the biblical texts and words and extra-biblical ones such as the structure of prayer). Abulafia uses the numerical equivalence in a manner that is reminiscent of the exegetical technique of philosophically oriented homonyms: he uses the linguistic methods in order to transfer the meaning of one type of nomenclature-the traditional one, in our case "the

58 See Imrei Šefer, 190.

59 Psalms 68:5.

60 For the translation and analysis of the original text, see Idel, Absorbing Perfections, 89. See also my Enchanted Chains, 149-51.

61 See Idel, The Mystical Experience, 105-8. Indeed, the third verse of this poem states מהחיות באותיות משיבים, which means "the beasts answer by means of letters."

62 For the various meanings of this term in Maimonides, see David R. Blumenthal, "Maimonides on Angel Names," in Hellenica et Judaica: Hommage à Valentin Nikiprowetzky ז', eds. André Caqout, Mireille Hadas-Lebel, and Jean Riaud (Leuven: Peeters, 1986), 367-68. For the Seat of Glory being understood by some of the Maimonideans as pointing towards the encompassing sphere, see Ravitzky, "The Thought of Rabbi Zerahyah," 258-68.

63 Teva' ha-Lev ["the nature of the heart"] = Kisse' ha-Kavod ["the Seat of Glory"] = 118. See Abulafia’s Sefer ha-Hešeq, 70; Commentary on Sefer Yeșirah, 31; Oșar 'Eden Ganuz, 2:2, 224; Šomer Miṣwah, 47; and Mafteah ha-Šemot, 114. The reiteration of this gematria shows that it was rather important for Abulafia. On the gematria $118=$ kohen gadol, see also chapter 24 above. 
Seat of Glory"-into a philosophical one, "the nature of the heart." I would like to emphasise the resort to the Hebrew medieval neologism teva' that occurs in philosophical texts.

While Muslim and Jewish philosophers took an allegedly polysemantic approach to words in order to solve the quandaries generated by theologically problematic terms, Abulafia also used the numerical equivalences in order to insert-though, it should be admitted, in quite an arbitrary manner-the new messages without always appealing to the philosophical pseudo-semantic approach of the homonyms or equivocation, which in my studies means allegorisation, which is essentially lexical. He assumes that the semantic potential of the consonants that constitute certain words ought also to be investigated by their numerical value (gematria) and by means of combinations of letters. This double exegetical method, which is often combined, is characteristic of his approach and only rarely found outside Abulafia's Kabbalistic school.

While the anonymous authors of the Hekhalot literature, some of the Hasidei Ashkenaz, and most of the Kabbalists were concentrating some of the major aspects of their esotericism on the "objective" structure of the supernal worlds, including the divine one, and while philosophers were concerned with understanding the natural world, Abulafia was much more concerned with the transformation of the human intellect through its actualisation and subsequent universalisation. The ecstatic Kabbalist was ready to adopt elements from a variety of philosophical sources, some of which have been mentioned above, to which we may add an interest in astronomy and some form of astro-magic, as well as other types of sources, some of which will be dealt with in a future study.

However, Abulafia was no more an astro-magician, theurgist, or theosophist than he was an astronomer, despite the substantial place the latter domain occupies in his discussions and especially in the imagery found in his visions. In any case, he was incomparably more interested in using astronomical imagery than he was in theosophical or theurgical imagery (that was interpreted allegorically), an issue that still awaits a balanced and competent inquiry. ${ }^{64}$

In any case, Abulafia was much more a "philosophically astute" Kabbalist, as Warren Zev Harvey puts it, ${ }^{65}$ than an astro-magician, theosophist, or theurgist; the question is whether the different descriptions can actually coexist so simply, despite my allowance for what I call conceptual fluidity. My answer is that not all of these scholars' attributions are actually appropriate; even those that somehow fit Abulafia's thought as I understand it do not play the same role in its broader economy.

64 For Abulafia's use of astronomy, see Idel, Saturn's Jews, 52-55. For other examples, see Sitrei Torah, 174; the introduction to Mafteạ̣ ha-Hokhmot, 40-41; Mafteaḥ ha-Šemot, 128; Commentary on Sefer Yeșirah, 34-35; and especially in many cases in Oșar 'Eden Ganuz, where he also displays a good acquaintance with the calculations related to the secret of intercalation. This astronomical register in his thought deserves a special analysis in itself.

65 See chapter 5 note 166 above. 
In any case, without clearly differentiating between what is marginal and what is central in Abulafia's writings, either statistically, conceptually, or structurally, a confused picture composed of some details belonging to a broad corpus emerges in scholarship. Reading Abulafia in accordance with the national-historical registernamely, according to the particularist attitude, as if it were his main messageand at the same time ignoring the centrality of the spiritual-atemporal register, is an example of such a confusion between Abulafia's secondary and main intentions.

The question is whether Abulafia was operating with more than one basic profound structure in his writings, which were composed over his twenty years of literary activity, or with more than one, diachronically, as Joseph Gikatilla and Moses de Leon did. The possible answers to this question should involve a detailed analysis of Abulafia's theology; namely, of his many discussions on his concept[s] of God, a topic which is still a desideratum in research. Without a prior and more comprehensive analysis of this issue, tentative as it may be, it is very difficult to understand Abulafia's various approaches to sefirot or his pantheism (which, in my opinion, is not panentheism) in their much wider framework, which has been the dominant or core approach to this issue. ${ }^{66}$

In my opinion, we should assume the existence of one such profound theological structure, the noetic one, which, when combined with techniques of attaining the ideals based on this structure, can be called the ecstatic model that permeates all Abulafia's extant writings and limits his conceptual fluidity. Within this more general structure, adopted from the Andalusian thinkers, Abulafia could experiment with a variety of theological concepts without systematically or dogmatically subscribing to any one of them. However, the dominant theology explicit or implicit in his many fragmentary discussions of the topic is deeply influenced by philosophical terminology, despite Abulafia's claims to the contrary. ${ }^{67}$

However, what counts more for a proper portrayal of Abulafia is less his specific theology and more the manner in which he presents himself, either as a prophet, Messiah, or prophetic Kabbalist, whatever the conceptual sources he used and misused were. His free attitude towards the linguistic articulations of many of his sources, biblical and otherwise, whose specific formulations he does not refrain from deconstructing, introducing his own views into the new combinations of letters (which he called giving or innovating a form or a new meaning), which are mainly concerned with spiritual processes, explains why he was ready to adopt concepts and phrases from a variety of sources whose general worldview he did not necessarily agree with. This "informing" of the interpreted texts (including the Torah) with meaning extracted from philosophical sources (that is, philosophical eisegesis)

66 The limited pantheism or immanentism may be related to Averroes's view. For a similar phenomenon among the Maimonideans, see Dov Schwartz, "Divine Immanence in Medieval Jewish Philosophy," JJTP 3 (1994): 249-78, especially 251-53.

67 See Oșar 'Eden Ganuz, 2:9, 279. I hope to deal with this passage and its implications for understanding Abulafia in more detail elsewhere. 
after the letters had been permutated is especially characteristic of this Kabbalist, who was ready to impose his views in such an arbitrary manner. ${ }^{68}$ As an anonymous Kabbalist who was related to Abulafia's Kabbalah puts it, by means of the radical forms of exegesis, it is possible to work as a potter does with the clay he uses. ${ }^{69}$

By this sharp shifting of weight from exegesis to eisegesis, the interpreting personality and the intellectual background become much more pronounced. Instead of a crisical arcanisation that prompts the interpreter to infuse the sacred text with new secrets stemming from external sources because of the crisis in the cultural perception of the scripture and other Jewish religious literature, as may be the case in Maimonides's two major projects, ${ }^{70}$ in the case of Abulafia, we may speak about the feeling of empowerment of the individual whose experiences and ideas are conceived as more important than the interpreted text. The crisis is seen much more in the ordinary audience's inability to transcend its inferior state from the cognitive point of view, while he himself claims the plenitude of experience, as the comparison to the ecstatic experience of the high priest shows. Moreover, with Abulafia, the allegorical interpretations were not a matter of external wisdom, but part of Jewish tradition as already expressed in the book that he conceived to be the most important in the world, The Guide of the Perplexed.

In chapter 24 above, we discussed the problems involved in presenting the high priest as a prophet and thereby transforming ancient rituals involving animal sacrifices, blessings, and the pronunciation of the divine name into occasions for attaining ecstatic experiences of a mental nature outside the sacred centre of ancient Judaism. By opening the exclusive status of the high priest to everyone through his allegorical interpretation, Abulafia performed a transgressive action, especially when understood in the context of the secret nature of his wider proposal and in terms characteristic of Rabbinic literature. This approach, which dissolves the centrality of the genetic criterion, may be one of the reasons why he was accused of heresy. In a way, here and in a few other cases, Abulafia approaches Rabbinic Judaism in a manner reminiscent of how Buddhism approaches the caste-oriented Hinduism: the historical and social frameworks were reinterpreted in a rather strong spiritualistic manner, implicitly undoing their original relevance.

\section{Appendix B: Or ha-Śekhel and Rabbi Nathan the Wise}

Let me turn to a passage found in the introduction to the book in which the parable of the pearl appears:

68 See "We-Zot li-Yehudah," 27.

69 Sefer ha-Ṣeruf, 153: כמו שהיוצר עושה בחמר.

70 See especially Moshe Halbertal, “What is Mishneh Torah? On Codification and Ambivalence,” in Maimonides after 800 Years, 88-90; Michaelis, "It is Time to Act for the Lord: [They] Violate[d] Your Torah," 24-26. 
In this book, I intend to bring benefit to those who begin the meditation on the divine name, and I shall show them the path of its knowledge, so that this treatise will be related to the knowledge of famous name, according to the path of the prophetic Kabbalah, just as the Account of Creation is related to the Account of the Chariot. Behold, I had been triggered to do so because of the love of two friends, who are lovers of wisdom, out of the best ${ }^{71}$ of the community of the sons of Messina on the island of Sicily, who brought me very close to them, and they follow my discipline and their names are Rabbi Abraham the Enlightened [Avraham ha-Maśkil] ${ }^{72}$ and Rabbi Nathan the Wise [Natan ha-Navon], blessed be his memory. ${ }^{73}$ Because after I had been with them for a few days, ${ }^{74}$ they asked me to briefly write down the general principles for them regarding the knowledge of the supreme and awesome name. And out of the true love that I had for them, ${ }^{75}$ I compelled myself to wilfully supply their requirement, and I know that this treatise will assist them and those like them very much. ${ }^{76}$

Abulafia's dedication of this book to his two disciples is indubitably part of his propaganda, intended to draw younger people to his Kabbalah and to convince them of his special role as prophet and Messiah. The practice of dedicating his books to his disciples is obvious in other cases as well; for example, Abulafia explicitly names the four students to whom he dedicated Sitrei Torah, as discussed in chapter 5 above. ${ }^{77}$ Oșar 'Eden Ganuz was dedicated to Rabbi Sa'adyah, Sefer ha-Hešeq was dedicated to Rabbi Jacob ben Abraham ben Shalom and Rabbi Sa'adyah, his 1287 book Šomer

71 In Hebrew mivhar, again a use of a noun that does not mean "election.” On this issue, see Appendix A.

72 Most probably, this is Rabbi Abraham ben Shalom, who was mentioned in the passage quoted from Oșar 'Eden Ganuz in chapter 5 above. As I have proposed elsewhere, this figure may be related to the much later Rabbi Abraham Shalom, an author active in Spain in the mid-fifteenth century. In his Neweh Šalom, there are some quotes from Abulafia's Or ha-Śekhel. See my Studies in Ecstatic Kabbalah, 66-67, 69-70, note 11.

73 This is certainly a mistake or a later addition by a copyist, since Rabbi Nathan lived for several years after his meeting with Abulafia, in my opinion as late as the last years of the 1280s.

74 This is an important indication as to the date of this book. Since Abulafia was most probably already in Messina in 1281, it seems that Or ha-Śekhel was written no later than 1283. Compare, however, the dating to 1285 by Shagrir, "The Parable of the Three Rings," 171 (though in her The Parable of the Three Rings, 37-42, this date is not mentioned), and Hames, Like Angels on Jacob's Ladder, 66, perhaps following Gross's view.

75 On the affinity between love and the transmission of secrets, see Hayyei ha-Nefeš, 121-22, and "Ševa' Netivot ha-Torah," 4.

76 Ms. Vatican, 233, fols. 1b-2a, 3:

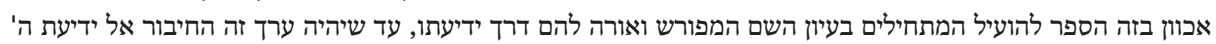

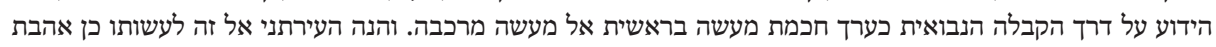

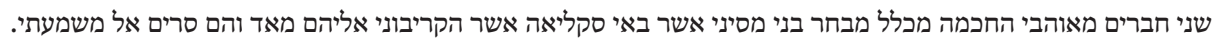

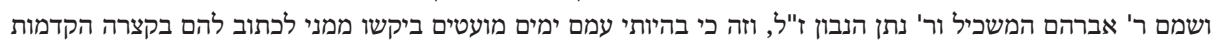

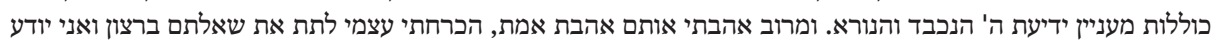

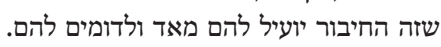
For some other occurrences of Rabbi Nathan's name in Abulafia's writings, see Idel, The Mystical Experience, 134.

77 See also Sefer Ge'ulah, 32. 
Mișwah was dedicated to a certain Rabbi Solomon ben Moses ha-Kohen on the occasion of his return to his native province of Galilee, and in the introduction to Sefer haMaftehot, his commentary on the Pentateuch, he describes seven students (three from Messina and four from Palermo) as the people who encouraged him to write the commentary. ${ }^{78}$ He envisioned his readers to be part of a potentially somewhat larger audience than his very few students-the phrase "those like them" recurs many times in Abulafia's writings-who could adopt his Kabbalistic theories. In this commentary, he quite surprisingly asserts that he only wrote this text for those who prophesy. ${ }^{79}$

However, there is only one author on his list of seven who would come to meet this requirement, according to the scant evidence we have: Rabbi Nathan ben Sa'adyah, whose mystical experiences were described in his Ša'arei Ședeq, though he himself did not claim any prophetic attainment. Nevertheless, in principle, Rabbi Nathan describes the phenomenon of prophecy in terms very close to Abulafia's. It is probably Rabbi Isaac of Acre who quotes his teacher as follows:

The wise and illuminated Rabbi Nathan, blessed be his memory, told me:80 "Know that the perfection of the secret of prophecy for the prophet is that he should suddenly ${ }^{81}$ see the form of his self standing in front of him. He will then forget his own self and it will disappear from him. And he will see the form of his self in front of him, speaking with him and telling him the future." 82

78 See the Introduction to Mafteah ha-Hokhmot, 1-2, and Mafteah ha-Šemot, 147. I hope to return to some facets of the Palermo aspects of the controversy with Rabbi Solomon ibn Adret.

79 See Mafteaḥ ha-Šemot, 163-64: כי זה הספר לא חובר אלא בעבור המתנבאים לבד. The context is an esoteric discussion on the revelation of the Torah. See chapter 10 note 202 above.

80 Presumably to Rabbi Isaac of Acre.

81 The assumption that the prophetic experience begins suddenly recurs in Rabbi Isaac of Acre, and if this text indeed also represents Rabbi Nathan's stance, Rabbi Isaac was influenced by Rabbi Nathan. The question is whether this sudden phenomenon is conceived as being preceded by some form of preparations, either intellectual or technical, or whether it is completely independent, which would represent a different view from both Maimonides and Abulafia. I prefer the first explanation. "Suddenly" seems to reflect a Platonic source, which in itself may point to an even earlier phenomenon. See Francis M. Cornford, Principium Sapientiae: A Study of the Origins of Greek Philosophical Thought, ed. William K. C. Guthrie (New York: Harper Torchbooks, 1965), 86. For the phenomenon of autoscopy in Abulafia, see Shahar Arzy, Moshe Idel, Theodor Landis, and Olaf Blanke, "Speaking with One's Self: Autoscopic Phenomena in the Ecstatic Kabbalah of the 13th Century," Journal of Consciousness Studies 12 (2005): 4-29, as well as Shahar Arzy and Moshe Idel, Kabbalah: A Neurocognitive Approach to Mystical Experiences (New Haven: Yale University Press, 2015). For an interesting parallel found in Avicenna and ibn Țufayl, see Wolfson, Language, Eros, Being, 512, note 312.

82 Preserved in the late fifteenth-century Rabbi Moses of Kiev, Šušan Sodot (Koretz: 1784), fol. 69b: אמר לי החכם המשכיל כ"ר נתן ז"ל. דע כי שלימות סוד הנבואה לנביא שפתאום יראה צורת עצמו עומדת לפניו וישכח את

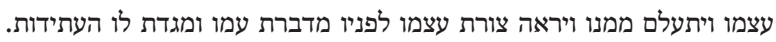

On this passage, see Scholem, On the Mystical Shape, 253; Gershom G. Scholem, "Ša'arei Ședeq, a Kabbalistic Text from the School of Rabbi Abraham Abulafia, Attributed to Rabbi Shem Tov (ben Gaon?)” [Hebrew], QS 1 (1924/25): 127-39; Gershom G. Scholem, “Eine Kabbalistische Erklärung der Prophetie als Selbstbegegnung," MGWJ 74 (1930): 289-90. See also Scholem, On the Mystical 
This means that Rabbi Nathan's experience did not include a vision of himself, although he belongs to ecstatic Kabbalah. Abulafia indicates in Or ha-Śekhel that he wrote the book for those who are intelligent and who have received the general principles that are related to God. ${ }^{83}$ Here, we have a description of the way in which he envisioned the two disciples, indubitably beginners, just as he later wrote his Commentary on the Pentateuch for seven people whom he believed should become prophets. He envisioned his audience in categories that were shaped by his expectations, or imaginaire, of the development of the eschatological process.

Interestingly enough, Abulafia does not dedicate Imrei Šefer, a book written in 1291, some months or a year after the date that Abulafia believed that the Messiah would come or be revealed, to any of his disciples. He mentions none of his students' names, perhaps an implicit sign that he had again been deserted by them as had happened in Capua in 1279. Then, in the early 1280s in Messina, for a short time at least, he again remained alone. Nevertheless, it is difficult to detect signs of despair or a significant change in the nature of his Kabbalah from this book. In my opinion, the absence of such signs of disappointment may be related to the importance of the other narrative or register, the third narrative, that could prevail over the date of the advent of the Messiah in history passing by, which belongs to the second narrative that is connected to a collective experience, as Abulafia's continuation of the dissemination of the third, spiritual-noetic register was, for him, quintessential. $^{84}$

Let me point out that the number of young Jews interested in philosophy around 1270 was much larger than those who were interested in Kabbalah, which means that the demographic pool for propagandistic activities was not among the theosophicaltheurgical Kabbalists, but among the young Maimonideans. One such student gleaned from this pool was Rabbi Nathan ben Sa'adyah, but in principle, this student could also have been someone with the intellectual profile of the famous poet Immanuel of Rome, cognisant as the latter was not only with philosophy, including Averroistic philosophy, but also with Sefer Yeșirah and the book Bahir.

Maimonides's purism as to which books were reliable and should be read and which should not did not hold too long and had certainly already become completely irrelevant by the third phase of Maimonideanism. However, in the case of Abulafia,

Shape, 259-60, 314, note 22. This is one more example of the existence of different types or perhaps levels of experience in ecstatic Kabbalah, a situation that prevents the reification of one type of experience. See also chapter 5 note 174 above. On the impact of such a view, though from another source, on a modern Hasidic Rabbi who perished in the Holocaust, see Ron Wachs, The Flame of the Holy Fire: Perspectives on the Teachings of Rabbi Kalonymous Kalmish Shapiro of Piaczena [Hebrew] (Gush Etzion: Mikhlelet Herzog, 2010), 236. See also chapter 27 note 199 above.

83 Ed. Gross, 40.

84 As to the possible postponement of the messianic date 1280 to 1290 , see Appendix D. 
his profound appropriation of the combinatory techniques should be seen as a major reason for his transcendence of the scholastic approach of the other Maimonideans.

In any case, an example of Abulafia's attempt to persuade a philosophically oriented thinker to accept his Kabbalah can be found in his epistle "Ševa' Netivot haTorah," written sometime towards the end of his life and addressed to a certain unidentified Rabbi Abraham. It seems that this letter is a response to a previous letter from Rabbi Abraham, who adopted a view according to which philosophy is higher than the "science of the Torah." ${ }^{85}$ Quite unusually for his writings, where he almost always uses the term "my son" in order to address his readers, Abulafia refers to this Abraham as someone who is as dear to him as a brother. From a perusal of the content of the letter, it seems that Abraham lived in a community that Abulafia had visited at some point in the past. ${ }^{86}$ In any case, it seems that we cannot identify him with one of the four students in Capua who were also called Abraham. Perhaps he is Abraham ben Shalom the Enlightened, who was mentioned above.

It is evident that Abulafia had initiated at least some of his disciples into his techniques in quite a short period of time, a practice that was described in some detail in Rabbi Nathan's Ša 'arei Ședeq. There, he claims that he was taught by his master, most plausibly Abulafia, who instructed him to practise his various techniques during a span of four months. ${ }^{87}$ Afterwards, he practised those techniques by himself and testified that they worked, though he took guidance from his master regarding the unusual events that occurred during those experiences. ${ }^{88}$ Interestingly enough, in Rabbi Nathan's description of his studies before meeting his Kabbalistic master and in the detailed enumeration of the Kabbalistic topics he studied with him, there is nothing related to sefirotic Kabbalah, though some themes related to the sefirot are found in his book.

This fact corroborates my assumption that the absence of a separate phase of studying sefirotic Kabbalah in Abulafia's life was practically (not rhetorically) necessary for approaching the more advanced form of Kabbalah, the ecstatic one. At least insofar as the details of the techniques described in Abulafia's handbooks are concerned-techniques which constitute one of Abulafia's most original contributionsas well as those in Rabbi Nathan's book, it is obvious that there is no vital connection between these techniques and the issues characteristic of theosophical Kabbalah, such as theosophical structures. In a way, the techniques reflect a pre-axial approach based on corporeal activities: oral and bodily movements are grafted onto the axial ideal of noetic activity. The complexity emerging from the combination of specific linguistic techniques and noetic ideals constitutes what I call the ecstatic model in my

85 As is implicit in Abulafia's epistle, 5, 7, 11.

86 Interestingly enough, in this epistle, he does not refer to theosophical Kabbalah at all, but sees the turn from philosophy as a means of bringing someone to his prophetic Kabbalah.

87 See Rabbi Nathan Har'ar, Le Porte della Giustizia, 478. Why Scholem speaks about "two months" in Major Trends in Jewish Mysticism, 150, and Gross about "three months" is not clear to me.

88 Rabbi Nathan Har'ar, Le Porte della Giustizia, 478-79. 
studies, which was described in detail in several of Abulafia's handbooks and which has no parallel in the Kabbalah of his contemporaries among the theosophical Kabbalists or philosophers.

Given the fact that these techniques are an original contribution both to Jewish mysticism and, I would say, also to the history of mysticism in general, and given the fact that he regarded them as very important, the absence of sefirotic themes in their fabric is a crucial fact for a proper understanding of Abulafia's approach. Moreover, some of his different handbooks describe paths for reaching mystical experiences (Hayyei ha-'Olam ha-Ba', Or ha-Śekhel, Sefer ha-Hešeq, and Imrei Šefer) and these practices are, in their profound structure, similar to each other, though in many details they diverge from one another. These divergences, though in many cases a matter of details, are nevertheless interesting since they differ both the sacramental manner in which mystical techniques are often described (e.g., as someone using the same technique all his life) and from the details of the performance of the commandments, which are described in the same manner in Rabbinic writings without any substantial difference.

However, in his various books, Abulafia experiments with the basic elements of his techniques and offers slightly different methods. This is an important case of conceptual fluidity within the framework of his profound noetic structure and within the more complex framework of what I call a model, which is constituted by a sequel that also contains a technique for reaching certain forms of experiences, techniques that I describe as anomian. The expectation is to attain some form of revelation, a mystical ideal that in our case is a prophetic experience, or, reaching even higher, to attain union with the supernal intellectual realm, to be experienced by means of applying one of his techniques.

Let us now turn to the two epithets that Abulafia confers on his two students in Or ha-Śekhel: "the enlightened" and "the wise." The meaning of these terms fits the title of the book: The Light of the Intellect. The book deals with the influx or overflow of the tenth, or lowest, cosmic intellect, which may also be a reference to the First Cause. In my opinion, the main intention of the treatise is to open the disciples' minds to the intellectual light by first resorting to vocal techniques that are formulated in great detail in the book and then later advancing to a more interiorised concentration on the mental level of the combinations of those letters.

In a way, Abulafia portrays his role vis-à-vis the two students to whom he dedicated the book as that of the cosmic Agent Intellect in relation to the human individual intellect. ${ }^{89}$ This ultimate goal is connected, as seen in the last passage, to the revelation of the divine name ' $H W Y$ which he considered to be the most secret of the divine names and which he imagined had first been disclosed to him a few years ear-

89 Compare to Or ha-Śekhel, 29. On the phrase Or ha-Śekhel, see The Writings of Rabbi Moses ibn Tibbon: Sefer Pe'ah, 103, or Rabbi Bahya ibn Paquda's Hovot ha-Levavot, trans. Judah ibn Tibbon, ed. A. Tzifroni (Tel Aviv: Mahbarot le-Sifrut, 1959), gate 10, chapter 1, 558, and Idel, The Mystical Experience, 209, note 22. 
lier. The comparison of this topic to the account of the chariot, a major esoteric subject in Abulafia's thought that in many cases is related to his speculations on the divine names, ${ }^{90}$ shows how important this name was for him.

The Kabbalist Nathan the Wise, who is mentioned in the introductory passage of this book, is to be identified, as I have proposed elsewhere, with Rabbi Nathan ben Sa'adyah Har'ar, the author of Ša'arei Ședeq. ${ }^{91}$ He is also most likely the author of some Kabbalistic collectanea that contain Sufi influences stemming from ibn Arabi's school in Damascus, which was assembled by Rabbi Isaac of Acre and described in a unique manuscript as having been authored by a certain "sage R. N." I decoded this acronym as a reference to his teacher Rabbi Nathan ${ }^{92}$ by means of two brief though quite important sentences: one in the name of "Rabbi Nathan the sage and the illuminate," adduced along with a short paragraph by Rabbi Isaac of Acre-entirely unknown by other sources-in a late fifteenth-century eclectic Kabbalistic work ${ }^{93}$ and the other in another interesting quote attributed to Rabbi Nathan, in the same Rabbi Isaac's Me'irat 'Einayyim. ${ }^{94}$

However, in our context, it is important to point out that these two Kabbalists, though decisively influenced by Abulafia in some important cases, were much more inclined towards Neo-Platonism and Sufism ${ }^{95}$ than to Neo-Aristotelian or Maimonidean approaches. They were disinterested in the political sort of esotericism found in Abulafia and in Maimonideanism, though they had no significant critique of naturalistic views, in the manner we have seen above in the writings of Rabbi Joseph Ashkenazi, as far as I can see. Rabbi Isaac, like his older contemporary Gikatilla, sometimes expressed anti-philosophical and anti-Maimonidean positions, though in many cases, their writings are informed by philosophical terminology.

In fact, this is also the case in theosophical-theurgical Kabbalah, whose esotericism is much less concerned with problems connected to the "Straussian" tensions between the religious, mythical mentalities of the multitude $\grave{a}$ la Eliade and those of the elite, if at all. Their writings deal much more with supernal attributes or categories (the sefirot) that organise traditional information in accordance with theosophical structures that served in the first century of the history of Kabbalah as a decadic

90 See Idel, Language, Torah, and Hermeneutics, 51-53.

91 See my introduction to Le Porte della Giustizia, 47-51, and Moshe Idel, "Rabbi Nathan ben Sa'adyah Har'ar, the author of Ša'arei Ședeq and Its Influence in the Land of Israel” [Hebrew], Šalem 7 (1992): 47-58.

92 See my Studies in Ecstatic Kabbalah, 73-90.

93 See Scholem, "Eine Kabbalistische Erklärung der Prophetie als Selbstbegegnung," 285-90; Idel, The Mystical Experience, 91-92; and my introduction to Le Porte della Giustizia, 330-45. See also Sagerman, The Serpent Kills, 123, note 47; 167, note 131, who was not then acquainted with the identification of the author of these passages as Rabbi Nathan ben Sa'adyah, which I demonstrated more than a decade ago.

94 See Chapter 6 note 244 above.

95 See my Studies in Ecstatic Kabbalah, 73-101. 
code for deciphering the alleged esoteric meaning of the scriptures, a phenomenon that I call arcanisation. ${ }^{96}$

Or ha-Śekhel, in which the parable of the son and the pearl is discussed, was dedicated to a Kabbalist named Nathan the Wise. It is difficult to avoid the connotations of the title of Gotthold Ephraim Lessing's famous play Nathan der Weise (1779), where a version of the parable of the three rings and a precious stone is found and the plot is set in the late thirteenth century. Is this resort to the phrase "Nathan the Wise" by the two authors a mere coincidence? I am inclined to give a negative answer, though so far I have been unable to establish a possible connection between the passages from Abulafia's book discussed above and Lessing's play or his general approach. Nor am I capable of finding, for the time being, a connection between them and Lessing's good friend, the famous Jewish philosopher Moses Mendelssohn, whom Lessing called "the second Spinoza," who could, thanks to his knowledge of Hebrew, have brought them to Lessing's attention. ${ }^{97}$ Perhaps new material that I am not acquainted with will be able to establish such a possible historical link. In any case, in both Abulafia's parable and Lessing's play, a precious stone is mentioned, in addition to Lessing's reference to the three rings. Finally, one of the thirty manuscripts of Or ha-Śekhel is located in a library in Berlin. ${ }^{98}$

The more universal approach found in Abulafia's book, though extremely elitist, is different from many medieval discussions and points to a phenomenological affinity with the German thinker that is worthy of a more detailed inquiry. In my opinion, a general affinity can be discerned between the two historical stages of the use of the parable about the true religion, even if they are unrelated historically: in both cases, the impact of the reverberations of ancient Greek philosophy has generated an atmosphere that was more open to a universal approach.

Like the early Maimonideans, the much later Maimonideans who were active in the second part of the eighteenth and nineteenth centuries were drawn to the more

\footnotetext{
96 For the codic function of the system of the ten sefirot, see my Absorbing Perfections, 280-89, and see Chapter 10 note 154 above. See also Idel, Middot.

97 As to Mendelssohn's interest in Kabbalah, especially in Rabbi Joseph Gikatilla's Ginnat Egoz, see Rivka Horwitz, Multiple-Faceted Judaism [Hebrew] (Be'er-Sheva: Ben-Gurion University Press, 2002), 11-74. As Horwitz has shown, Mendelssohn had a special interest in the divine name. For Nathan the Wise and Mendelssohn, see Alexander Altmann, Moses Mendelssohn: A Biographical Study (Philadelphia: Jewish Publication Society, 1973), 298-99, 569-70, 573-75, but the reason for the choice of "Nathan the Wise" as the title is not addressed.

98 Ms. Berlin, 122, Or. 8을 358, fols. 1a-59b. There is a rich bibliography on Lessing's views and sources. See the English translation of Lessing's Nathan the Wise, ed. George A. Kohut (New York: Bloch Publishing House, 1917), 117, where he translates Abulafia's parable without mentioning the name of Rabbi Nathan the Wise, or Yossef Schwartz, "Three Rings or Three Cheats: Revealed Religions and Pluralism between the Middle Ages and the Enlightenment," in Streams into the Sea: Studies in Jewish Culture and Its Content Dedicated to Felix Posen, eds. Rachel Livneh-Freudenthal and Elchanan Reiner (Tel Aviv: Alma College, 2001): 268-81, as well as Fraenkel, Philosophical Religions, $285-86$.
} 
naturalist and intellectualist proclivities in Maimonides and his esoteric thought. ${ }^{99}$ Solomon Maimon is perhaps the best example of the continuity between the two stages of Jewish thought, because he adopted Maimonides's name as his family name, wrote an incomplete commentary on the Guide in Hebrew entitled Give at ha-Moreh and quite a long exposition of the content of Maimonides's book in his autobiography, ${ }^{100}$ and understood the earliest form of Judaism that extended from the period of the Patriarchs to that of Moses to be a natural religion. However, Maimon distinguished between this phase of Judaism and the later ones, in which there are greater and smaller mysteries that also include the secrets of Kabbalah. ${ }^{101}$ His older contemporary, Moses Mendelssohn, regarded natural religion as mankind's first common religion.

In the nineteenth century, first editions of books written by Maimonideans were quite widespread as part of the renewal of interest in a "rational" Judaism, especially among Jews in Germany and in some areas where Jews were influenced by the Western Enlightenment. ${ }^{102}$ It seems quite plausible that Maimonideanism, both in the form of Maimonides's own major books and the vast literature of his followers, including Abulafia's writings, left significant traces, directly-and in more cases indirectly-on pre-modern philosophers such as Spinoza and Maimon. ${ }^{103}$ They adopted a much more naturalist approach to religion and to reality, as well as a more incisive and explicitly critical stance towards the sacred scriptures, which indeed explains why they were persecuted. Maimon's perception of Judaism as a religion, not only of Kabbalah, was greatly influenced by the discourse of mysteriology; he not only de-

99 For Strauss, Maimonides was part of the essentially esoteric medieval Enlightenment, while he understands the modern Enlightenment as essentially exoteric; see Sheppard, Leo Strauss and the Politics of Exile, 73. However, some of Maimon's writings do not fit this characterisation.

100 Salomon Maimon, Salomon Maimons Lebensgeschichte, repr. ed. (Frankfurt: Jüdischer Verlag, 1995), 240-315.

101 Solomon Maimon, An Autobiography, trans. John Clark Murray (Urbana: University of Illinois Press, 2001), 176-85. For Maimon's interpretation of Maimonides's esotericism, see Moshe Idel, "Solomon Maimon and Kabbalah," Kabbalah 28 (2012): 74-79. For Maimonides's impact on Maimon's philosophy, see Samuel Atlas, From Critical to Speculative Idealism: The Philosophy of Solomon Maimon (The Hague: Martinus Nijhoff, 1964).

102 See the rather general survey by Fishel Lachover, "Maimonides and the Hebrew Haskalah in Its Beginnings” [Hebrew], in 'Al Gevul ha-Yašan we-ha-Hadaš (Jerusalem: Mossad Bialik, 1951): 97-107, and the more incisive study by Eliezer Schweid, "From the 'True Wisdom of the Torah' and the 'Secret of the Unity of Faith' to 'Philosophy of Religion,"' Iyyun 20 (1969): 29-59; Abraham P. Socher, The Radical Enlightenment of Solomon Maimon: Judaism, Heresy, and Philosophy (Palo Alto: Stanford University Press, 2006); Allan Arkush, Moses Mendelssohn and the Enlightenment (Albany, NY: SUNY Press, 1994); Gideon Freudenthal, No Religion without Idolatry: Mendelssohn's Jewish Enlightenment (Notre Dame: Notre Dame University Press, 2012); and Daniel B. Schwartz, The First Modern Jew: Spinoza and the History of an Image (Princeton: Princeton University Press, 2012), 93-103.

103 Maimon was influenced by Rabbi Moses Narboni's commentary on the Guide. See Maimon's Giv'at ha-Moreh, eds. Shmuel H. Bergman and Nathan Rotenstreich (Jerusalem: Israel Academy of Sciences and Humanities, 1965), 96, 99. 
scribed great and small mysteries in Judaism, but also those of Hasidism (a predominantly exoteric type of popular Kabbalah), which he knew from his own brief experiences, in terms of a "secret society," as if it were similar to the recently founded sect of the Bavarian illuminati. ${ }^{104}$

In a way, Maimonides created a religion of his own, as Abulafia's verse from his poem about the religion of Moses and Maimonides that was quoted above formulates it, which is esoteric, and we have surveyed here only a few of its persistent variants. Interestingly enough, it was a statement on esotericism by Maimon's contemporary Lessing that served Leo Strauss when he exemplified his own approach. ${ }^{105}$ In my opinion, esotericism and universalism are not exclusive approaches, especially when they are related to particularistic societies. After all, Strauss elaborated on how this approach informed the history of Western philosophy, and he may be considered part of what can be called the twentieth-century Maimonideans. As the late Professor Shlomo Pines told me, Strauss reached his theory on philosophical esotericism by beginning with reading the medieval commentaries on The Guide of the Perplexed that could be found in print at that time.

\section{Appendix C: Abulafia: From Christian Trinities to Noetic Triads or Vice Versa?}

Abulafia's image has undergone a variety of metamorphoses in modern scholarship. ${ }^{106}$ However, the bizarre presentations of his image began much earlier, at the very beginning of scholarship on Kabbalah. ${ }^{107}$ Such a strange presentation can be seen in Meyer H. Landauer's claim that Abulafia wrote the Zohar, an issue that was duly rejected by Adolph Jellinek. ${ }^{108}$ Landauer was the first serious reader of Abu-

104 Maimon, An Autobiography, 151-69, 185.

105 Strauss, Persecution and the Art of Writing, 28, 182. See also Sheppard, Leo Strauss and the Politics of Exile, 107-8. That Lessing embraced an Averroistic view of humanity as a species that can be educated in the course of history, see Shlomo Pines, "La philosophie dans l'économie du genre humain selon Averroès: une réponse à al-Fārābī?”, in Multiple Averroès: Actes du colloque international organisé à l'occasion du 850 anniversaire de la naissance d'Averroès, Paris 20-23 septembre 1976 (Paris: Les Belles Lettres, 1978): 189-207, reprinted in Studies in the History of Arabic Philosophy, ed. Sarah Strouma, vol. 3 of The Collected Works of Shlomo Pines (Jerusalem: Magnes Press, 1997): 374-75.

106 See Ronald Kiener, "From Ba'al ha-Zohar to Prophet to Ecstatic: The Vicissitudes of Abulafia in Contemporary Scholarship,” in Gershom Scholem's Major Trends in Jewish Mysticism 50 Years After, 145-59. See also Isaiah Tishby, The Wisdom of the Zohar: An Anthology of Texts, trans. David Goldstein (London: Littman Library, 1991), 1:48-49.

107 For the first part of this appendix, I draw from my article "Abraham Abulafia and the Pope." 108 See his small but ground-breaking monograph, Moses Ben Schem-Tob de Leon und sein Verhältnis zum Zohar (Leipzig: s.n., 1851). The parallels he found between de Leon's Hebrew writings and the Aramaic passages in the Zohar are very solid and have not been shaken even by the more recent find- 
lafia's manuscripts that could be found in the Bavarian library in Munich, and his wild speculations had scholastic consequences for some decades, despite the fact that Jellinek refuted them soon after his premature death.

In what follows here, I will summarise these scholars' discussions and indicate the points of legend regarding Abulafia, all of which are merely the fruit of these scholars' and historians' wild imaginations, a tendency still evident, mutatis mutandis, even in some historical presentations in recent scholarship. The foundations of the legend of Abulafia's meeting with the pope and its alleged content were laid by Meyer H. Landauer, the founder of the studies of Kabbalah in the mid-nineteenth century. He writes:

\begin{abstract}
Im Monat Ab des Jahres 5041 ging er von Capua nach Rom. Hier ging er am ערב ר"ה zum Pabst, und suchte ihn zu bekehren; hätte aber diese Kühnheit beinah mit dem Leben bezahlen müssen. שתי פיות Er ist nur dadurch vom Feuertod gerettet worden, daß ihm Gott, wie er sich ausdrückt hat wachsen lassen, wahrscheinlich hat er als Zweizüngler gesprochen, wie er es auch in seinen Schriften thut. ${ }^{109}$

In the month of Av in the year 5041, he went from Capua to Rome. There, on the eve of the new year, he went to the pope and tried to convert him, almost paying for this audacity with his life. He was saved from death by fire, since God, as he put it, allowed him to grow two mouths; he probably spoke equivocally, as he also does in his writings.
\end{abstract}

Clearly, Landauer derives many of the particular elements of his story from a single source: the Commentary on Sefer ha- ${ }^{'}$ dut. ${ }^{110}$ He includes a number of incorrect details, such as the year 5041 (instead of 5040) being the year that Abulafia arrived in Rome. He also omits the fact that the pope was at that point not in Rome, but in Soriano nel Cimino. However, what is most important in Landauer's report is that Abulafia went to the pope on the eve of Rosh Hashanah. Details such as the pope's refusal to meet him and the pope's sudden death are omitted and the impression is created, by means of the German verb "ging," that Abulafia succeeded in meeting him. Moreover, he states that Abulafia's purpose in this encounter was to convert the pope to Judaism: "suchte ihn zu bekehren."

An additional error in Landauer's report is his emphasis on the opinion that Abulafia was saved from the flames due to his "two mouths," which is, on the basis of the single description we have, also untrue. Abulafia was also apparently not imprisoned in Soriano, but in Rome. It was in Soriano that the wood was set aside for his immolation, but the "two mouths" story, with all the ambiguity that this expression contains, is described as an event that occurred before Abulafia's

ings in the field, which have substantially restricted the role of Moses de Leon in the composition of the Zoharic literature.

109 Meyer H. Landauer, "Vorläufiger Bericht über meine Entdeckung in Ansehung des Sohar," Literaturblatt des Orients 6 (1845): col. 382.

110 Landauer knew Abulafia's commentaries on his prophetic works that are contained in $\mathrm{Ms}$. Munich, 285 very well and briefly described them in Literaturblatt des Orients, col. 118. 
journey to Soriano, or at most on the day of his arrival there, not during a [non-]meeting with the pope.

An additional contribution Landauer made to the creation of the legend comes by way of a bibliographical error. His fantastic statement regarding the "Trinity" in Abulafia's writings is based on his quote from a poem contained in Munich Ms. 285, situated between Imrei Šefer and the epistle "We-Zot li-Yehudah," both of which were written by Abulafia. The poem reads:

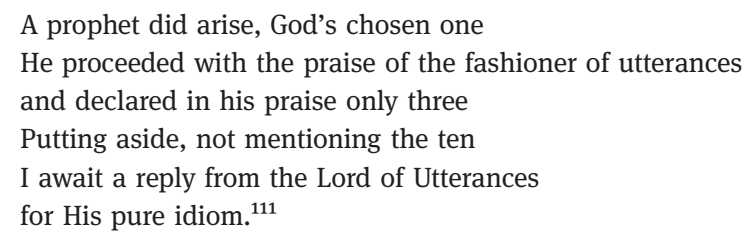

Landauer explains the content of these lines as follows: "In a poem [...] he declares that he abandoned the ten sefirot and he settled on three." 112 And so, Abulafia became someone who forsook the Kabbalistic concept of the ten sefirot, substituting in its place a Kabbalah founded on only three sefirot. In Landauer's eyes, this is a clear indication of Abulafia's Christianising tendency.

However, the poem upon which Landauer relies was not written by Abulafia. It was accidentally inserted into that text between two of his writings, and it was actually authored by the Provençal Kabbalist Rabbi Asher ben David, who lived a generation before Abulafia in Catalonia. ${ }^{113}$ The poem speaks about the biblical Moses, not about Abulafia; "a prophet did arise, God's chosen one" undoubtedly refers to Moses. The poem refers to the thirteen attributes, of which, according to some Rabbinic sources, Moses chose three: "the great, the mighty, and the awesome." Therefore, the poem does not at all imply Abulafia's forsaking of the ten sefirot. When "Abraham" is mentioned later on in the poem, it is the biblical patriarch, not the medieval Kabbalist, who is discussed.

The decisive stage in the collection of additional details concerning the "encounter" between Abulafia and the pope was first reached by the most important and most famous of Jewish historians, Heinrich Graetz. Basing his analysis on Landauer's mistakes, Graetz adds his own personal touches, writing:

111 Landauer, Literaturblatt des Orients, col. 483:

וקם נביא בחיר האל ופתח, לשבח לגוזר מאמרות-ולא זכר שבחיו רק שלשה, והניח ולא פקד עשרות-אצפה מענה מאל

אמורות-לאמרותיו אמרות טהורות.

112 Literaturblatt des Orients, "In einem Gedicht [...] Macht er sich groß daß er die 10 Sefirot verlassen, und dafür drei gesetzt [hat]," a statement based on Landauer. See Jellinek's German introduction to his edition of Sefer ha-Ot, 65. See also Ezriel Guenzig, Abraham Abulafia: His Life, His Doctrine, and His Spiritual Propensity [Hebrew] (Krakow: J. Fischer, 1904), 22.

113 The original version of the poem was printed by Daniel Abrams in R. Asher ben David: His Complete Works and Studies in His Kabbalistic Thought (Los Angeles: Cherub Press, 1996), 28-31. 
In the end, a spirit of madness fell upon him. He was to meet with Pope Martin IV in Rome, in an attempt to prevail upon him to remove the robes of his high office and become Jewish. The Pope heard the words of this mad Kabbalist Jew, and enraged, he put him in prison. He was incarcerated for 28 days and was released; spared from the fiery verdict of the Inquisition because, as he put it, God graced him with two mouths. There is reason to suppose that Abulafia told the Pope that in place of the ten sefirot he upholds a doctrine of three. The Pope found this at least partially satisfactory and set him free. Upon being released he was permitted to move about freely in Rome. ${ }^{114}$

Uncritically relying on Landauer, Graetz understands the purpose of Abulafia's meeting with the pope as an attempt to bring about his conversion to Judaism. He also adds many "significant details" that do not appear in Landauer's account. For instance, he identifies the pope Abulafia went to meet as Martin IV. This supplementary detail was the result of Graetz's acceptance of Landauer's 5041 (1281) date for Abulafia's meeting with the pope, as Martin IV was elected pope in $1281 .^{115}$

This mistake made other pure inventions possible: according to Graetz, the pope spoke to Abulafia and the latter's life, so the great historian speculated, was spared thanks to the fact that his beliefs were found to be "partially satisfactory." Whence did Graetz derive these details? Again, the single possible source is the passage from Landauer cited above. Accordingly, it was reasonable for Graetz to assume that Abulafia had confessed a belief in the Trinity in the presence of the pope in order to survive. So, too, the interpretation of Abulafia's expression "two mouths" as implying his partial acceptance of the doctrine of the Trinity is at least in part derived from Landauer. In such a manner, a legend was created whose origin lies in Landauer's faulty quotations from the Commentary on Sefer ha-'Edut, in which he omits several crucial details, and the erroneous reliance on Rabbi Asher's poem as a reflection of Abulafia's approach. It continued with Graetz's attempt to accept Landauer's story, resulting in him filling in significant but fabricated details derived from Landauer's "historical" evidence. The irony of this is that Graetz, the pre-eminent "rationalist" historian, turned himself into the composer of quite a fantastic legend.

Interestingly enough, in addition to this fabrication of details, it should be mentioned that it was Graetz who first published the entire Hebrew original of the Commentary on Sefer ha-'Edut, which actually contradicts the legend he composed, and

114 Heinrich Graetz, Divrei Yemei Yiśra'el, vol. 5, trans. Shaul P. Rabinovich (Warsaw: Ahiasaf Press, 1897), 185. The English version of these discussions is shorter and differs in some details, but nevertheless includes the issue of Abulafia's confession of the Trinity. See Heinrich Graetz, History of the Jews, trans. Bella Löwy, vol. 4, repr. ed. (Philadelphia: Jewish Publication Society, 1967), 7. Shimeon Berenfeld also bases himself on Heinrich Graetz. See his Da'at Elohim (Warsaw: Ahiasaf Press, 1899), 386, note 1.

115 Martin IV was elected pope some months later on February 22, 1281, when Abulafia was most probably already in Messina. See also the assumption that Abulafia attempted to meet Pope Martin IV in 1281 made by Nicholas Goodrick-Clarke in "Ramon Lull's New World Order: Esoteric Evangelism and Frontline Philosophy,” Aries 9 (2009): 188. 
who translated Abulafia's text into German. Surprisingly, he noticed nothing that necessitated a substantial revision of his earlier erroneous historical report. ${ }^{116}$ Thus, gross mistakes and even fabrications about Abulafia's thought are not of recent scholarly invention, but rather are the result of superficial readings of his writings. For this reason, in chapter 27 of this book, I recommend that readers of Abulafia should not rely on history as shaped by historians, but should rather check everything from the very beginning. In this way, one can offer one's own picture rather than relying on the imagination of others, including historians.

Graetz's publication of the original Hebrew text did not succeed in clarifying the true nature of this affair for scholars writing much later. For example, Israel Friedlander, an accomplished scholar of messianic thought, writes that Abulafia "renounced his belief in the presence of the Pope [...] in order to escape death"117 and David Neumark, a distinguished historian of Jewish thought, writes that "according to modern writers, Abulafia formulated this doctrine (i.e., the Trinity) in order to placate his captors in Rome and save his life-indeed they set him free." context, when dealing with legends created and disseminated by distinguished historians concerning Abulafia's attempt to meet the pope, let me point out that I am not sure whether or not Sagerman's claim that Abulafia was imprisoned before the pope died and released sometime afterwards also stems from Graetz's account. ${ }^{119}$

However, what can be shown is that Abulafia's acknowledgment of the Christian Trinity was an invention by Meyer H. Landauer and repeated uncritically by Heinrich Graetz. It has recently been attributed to Abulafia on the grounds of some of his other texts that the two nineteenth-century scholars mentioned above could not have seen as they were in manuscripts and libraries that were not accessible to them. Probably unaware of the fantastic nature of the nineteenth-century claims of his illustrious predecessors, or of my Hebrew article on the topic of Abulafia's attempt to meet the pope, Sagerman attempts to demonstrate that some forms of trinity that were influenced by Christianity were indeed part of Abulafia's doctrine, though they were accepted with some due changes.

\footnotetext{
116 Heinrich Graetz, “Abraham Abulafia der Pseudo-Messias,” MGWJ 36 (1887): 557-58. For a similar approach to some historical accounts, see Marianna Ruah-Midbar Shapiro, "Historians as Storytellers: A Critical Examination of New Age Religion's Scholarly Historiography,” Alternative Spirituality and Religion Review 10 (2019): 1-24.

117 Israel Friedlander, “Jewish-Arabic Studies,” JQR 3 (1912/13): 287, note 428: “[Abulafia] renounced his belief in the presence of the Pope [...] in order to escape death.” See also Louis I. Newman, Jewish Influence on Christian Reform Movements (New York: Columbia University Press, 1925), 179, and William J. Bouwsma, Concordia Mundi: The Career and Thought of Guillaume Postel (1510-1581) (Cambridge, MA: Harvard University Press, 1957), 141.

118 David Neumark, Toledot ha-Filosofiah be-Yiśra'el (New York: A. Y. Shṭibl, 1921), 1:67-68.

119 Sagerman, The Serpent Kills, 2. I do not know the Hebrew source for Sagerman's claim that Abulafia was imprisoned by the pope's forces after his departure from Spain [sic], since he does not mention any date, place, or source for his statement. See The Serpent Kills, 28.
} 
Let me begin the discussion of this allegation with Abulafia's explicit statement as to the manner in which he envisioned the Christian Trinity. In his epistle "We-Zot li-Yehudah," he writes:

The sages of the sefirotic Kabbalah thought to unify God and to flee from the belief in the Trinity [šilluš], and they had [envisioned] Him as a decad ['išseruhu], like the Gentiles say that He is three and three are one, so some of the masters of Kabbalists believe, and they say that the divinity is ten sefirot, and the ten are one and they multiplied Him at the maximum and compounded Him at the maximum, and there is no greater multiplication than ten. ${ }^{120}$

Here, we have a mention of the Christian Trinity in the context of a sharp critique of Kabbalistic theosophy issued in a treatise written by another Kabbalist. This important passage has not been given its due attention in the new wave of scholarship on Abulafia since it complicates the harmonious picture of Kabbalah cum Christianity. For example, surprisingly enough, this was not addressed by Sagerman in his book dedicated to Abulafia's attitude towards Christianity. Nor has he mentioned the other clear references to the Trinity that can be found in his Commentary on Sefer ha-'Edut: "I am confident-he says-that no illuminate will be duped to believe the dictum of those who say that God is one substance, which has three properties."121

However, the clear content of Abulafia's statements notwithstanding, Sagerman's general approach merely follows Wolfson's incarnational interpretation of Abulafia: he writes of a co-optation of the Christian Trinity. ${ }^{122}$ In this vein, he sees in Abulafia's discussions of the Trinity a double tendency: one towards adopting it and another one towards amending its idolatrous content. ${ }^{123}$ Let me therefore address these dis-

120 Ed. Jellinek, 19, corrected according to Ms. New York, JTS 1887:

שבעלי הקבלה הספיריית חשבו לייחד השם ולברוח מאמונת השלוש ועשרוהו וכמו שהגוים אומרים הוא שלשה והשלשה

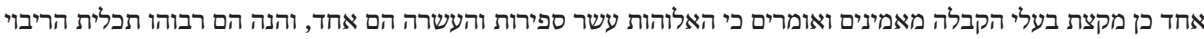
והרכיבוהו תכלית המרכבה ואין ריבוי אחר העשרה מאים

For another sharp critique of the belief in a divine Trinity, see Sefer ha-Hešeq, 54, and Sagerman, The Serpent Kills, 146-47.

121 Printed in Maṣref ha-Śekhel, 60:

ואני בטוח ששום משכיל לא יתפתה להאמין מאמר האומרים שהאלוה עצם אחד ויש לו שלש סגולות. See also Mașref ha-Śekhel, 59-60, where he speaks negatively about the faith in one substance and three attributes. The resort to the Hebrew term to'ar here may refer to the Christian view of three persons in the deity.

122 The Serpent Kills, 249: "This Jewish mystical trinity is both a cooptation, on Abulafia's part, of core Christian doctrine and a subversion of idolatry." Compare Landauer's view of Abulafia as a "rationalist Christian," Literaturblatt des Orients 6 (1845): col. 473, and Scholem, Major Trends in Jewish Mysticism, 379, note 35. The claim about this Kabbalist's cooptation of the Trinity is another instance of the scholarly ignorance of the vital impact of Maimonides's thought on Abulafia.

123 The Serpent Kills, 84, where he speaks about Abulafia's proclivities towards the Trinity and the incarnation. See also The Serpent Kills, 218, 225, 248, etc. Unlike Wolfson, who often qualifies incarnation, speaking, for example, about “textual incarnation," Sagerman speaks about incarnation without any further qualification. In my opinion, this term obscures much more than it clarifies, since we may well understand the phenomena as different forms of embodiment. 
cussions on the basis of our assumptions above about Abulafia belonging to the Maimonidean camp.

One of the most frequently recurring topics in Abulafia's writings is his adoption and elaboration of the well-known Aristotelian and Maimonidean theory of the possible identity between the intellect, the act of intellection, and the intelligibilia during the noetic process. ${ }^{124}$ He mainly uses the medieval forms of Śekhel, maśkil, and muśkal, ${ }^{125}$ but he also sometimes uses yode' $a$, da'at (or madda'), and yadu' $a^{126}$ for the noetic triad. ${ }^{127}$ Though three different concepts are involved, they are conceived as becoming one indistinguishable unity in the moment of intellection.

Discussions about intellection are an integral part of Abulafia's profound noetic structure and may be detected in dozens of places in his writings. They follow the lead of Maimonides's thought and also, to a lesser extent, that of ibn Ezra, the Andalusian thinkers, and the Maimonideans, who are quintessential for understanding Abulafia's thought. This means that the intellectual nature of both the human and the divine activity as a union between three distinguished components is well-established both in his thought and in his speculative sources, despite the complete absence of these terms in the biblical and Rabbinic literature. These discussions can be understood on their own without resorting to other conceptual structures like Christianity.

The question that should therefore be asked is how the basic noetic structure that so profoundly informed Abulafia's thought attracted and modified other types of triads and reinterpreted them by means of their noetic contents, such as the triads of ḥošeq (desirer), ḥešeq (desire), and ḥašuq (desired); ${ }^{128}$ regeš (sense), margiš (the

124 See Afterman, Devequt: Mystical Intimacy, 110-24, 139-58, and Even-Hen, "Maimonides’s Theory of Positive Attributes." For the impact of Aristotelian noetics on Maimonides in more general terms, see Charles Manekin, "Maimonides and the Arabic Aristotelian Tradition of Epistemology," in Beyond Religious Boundaries: Interaction and Intellectual Exchange in the Medieval Islamic World, eds. David M. Freidenreich and Miriam Goldstein (Philadelphia: University of Pennsylvania Press, 2011): 78-95. 125 See Mafteah ha-Ra'ayon, 64, 73; Or ha-Śekhel, 16-17, 108-9; Sefer ha-Hešeq, 3, 10, 33, 42; Imrei Šefer, 69, Untitled Treatise, Ms. Firenze, Laurenziana, Plut. II. 48, fol. 75b; "Ševa' Netivot haTorah,” 13, 19; Oșar 'Eden Ganuz, 1:3, 129; 130, 2:1, 200; Hayyei ha-Nefeš, 59; Commentary on Sefer ha- 'Edut, 61; as well as the passage translated above in chapter 17 from his epistle "Ha-Seder ha-Mithappekh"; Idel, Messianic Mystics, 71; and Idel, Studies in Ecstatic Kabbalah, 13-14, and the accompanying footnotes. See also Ner Elohim, 29. Sagerman marginalises the discussions on noetic triads that have nothing to do with Christianity, mentioning only one such example in passing. See The Serpent Kills, 66, 91.

126 Following Maimonides's terminology in Mishneh Torah, Hilekhot Yesodei ha-Torah, chapter 2, halakhah 10, Hayyei ha-Nefeš, 88, 97, or the Untitled Treatise, Ms. Firenze, Laurenziana, Plut. II, 48, fols. 70b, 75a, 75b, 79b, 90b, etc. See Warren Zev Harvey, "De la notion d'intellect-intelligent-intelligible chez Maïmonide," in Écriture et réécriture des texts philosophiques médiévaux, eds. Jacqueline Hamesse and Olga Weijers (Turnhout: Brepols, 2006): 253-62. See also Chapter 3 note 93 above.

127 See Hayyei ha-'Olam ha-Ba', 83.

128 Sefer ha-Hešeq, 10. 
person that senses), and murgaš (sensed); ${ }^{129}$ medammeh (the person who imagines), medummeh (the imagined), and dimyon (imagination); ${ }^{130}$ and Hokhmah, Binah, and Da $a t{ }^{131}$ However, he did not conceive the "true" meaning of the Christian Trinity as identical to these intellectual components; they do not constitute a hermeneutical grid that dictates the significance of the few cases in which the Christian Trinity is mentioned in his works. ${ }^{132}$

Let me present an example where the meaning is established by a certain philosophical background that Abulafia applies to the Christian material. In his Oșar 'Eden Ganuz, the ecstatic Kabbalist wrote about the first sefirah, called Ruah haQodeš (the Holy Spirit) already in Sefer Yeșirah, as follows:

\footnotetext{
The first, which is one [Alef], is the Holy Spirit, and was called one sefirah, and together with the second [the letter Bet] one, their meaning will be $A B$ [Av = father]. And from the third [figure] up to the tenth [figure, when all of them are added] ${ }^{133}$ means Ben [52], and their meaning altogether is Adonai [= 65], and whoever thinks otherwise cuts the branches and he will be accounted for [...] and the secret of Ha-AV, Ha-Ben [65 = the Father, the Son], amounts to Ben David Ba' [69= the son of David comes] and "he brings the prophecy [ha-nevu'ah $=69]$ in his hand." And indeed "he is the son" [hu' ha-ben $=69$ ] and "behold he is the father" [ha-av hino $=69] .{ }^{134}$
}

It is obvious that the three entities mentioned here are the Father, the Son, and the Holy Spirit. However, Abulafia is attempting to show how the procession going from the Holy Spirit to the Father to the Son is not a matter of a theological tenet; the order of the persons in this discussion is nothing like what can be found in Christian orthodoxy. Rather, it reflects a form of numerical order.

The letters of the Hebrew alphabet have a double meaning: as linguistic units, they form words, and as mathematical entities, they add up to numbers. Thus, the first letter of the Hebrew alphabet is interpreted here as a reference to the Holy Spirit, according to Sefer Yeșirah, where Abulafia takes the phrase sefirah ahat to mean

129 Commentary on Sefer ha-'Edut, in Mașref ha-Śekhel, 61.

130 Commentary on Sefer ha-'Edut, in Mașref ha-Śekhel, 61.

131 Sefer ha-Hešeq, 80.

132 Compare, however, the assumption that the "triads" in Abulafia are related to or evocative of Christianity in Sagerman, The Serpent Kills, viii, 83, 147, 220, note 123, 293.

133 Namely, $3+4+5+6+7+8+9+10=52=$ Ben .

134 1:1, 31:

ואמנם אמר כי הראשונה שהיא אחת היא רוח הקדש וקראה ספירה אחת, ועם השנית היה סימנם א"ב. ומן הג' ועד הי'

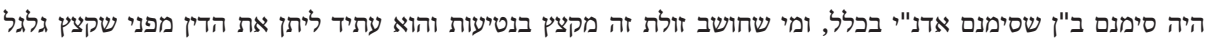

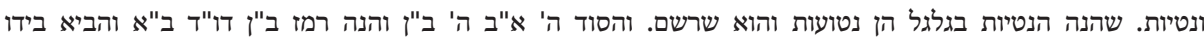

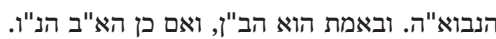

See Idel, Ben, 315-18, and Sagerman, The Serpent Kills, 86, who could benefit from the analysis in my book, were he to be acquainted with it. Compare also some themes found in this passage to a discussion in Sefer ha-Hešeq, 54. For the Neo-Pythagorean Eudorus's view that distinguishes between the One and the Monad and the Dyad that both emerge from it, see Charles Kahn, Pythagoras and the Pythagoreans: A Brief History (Indianapolis: Hackett, 2001), 97-98. 
"number one." When the second Hebrew letter, Bet, is added to the first one, the word $A B$ ("Father") emerges. Then, when one adds up the remaining letters/numbers from three to ten, the figure 52 emerges; Ben ("Son"). An unorthodox imaginary that approximates the Christian Trinity is here built on speculations that are specific to Abulafia's thought, though the procession of the three divine powers in Christianity is not accepted.

The leading idea of the passage is that a certain type of Trinity is found in the ten sefirot, which in this context refer to the first ten numbers. This Trinity should be understood as one unity, a triunion, and any separation between its components is heretical. When the definite forms of the Hebrew characters of the Father and the Son ( $h a-A v$ ha-Ben) are calculated, they amount to 65, which is also the numerical value of the divine name Ad[o]nai when it is spelt elliptically without the Waw. Having construed the word $h a-A v$ together with ha-Ben, Abulafia changes the order of the letters

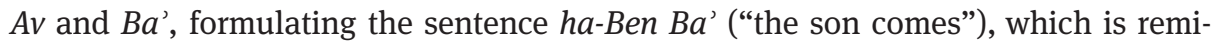
niscent of the traditional phrase "the son of David comes." This phrase amounts in gematria to 69, as does "he is the son" and "behold he is the father."

The phrase "the son comes," described in Jewish terms as "Ben David comes," which is an explicit messianic statement that draws on a Talmudic discussion, ${ }^{135}$ is here connected to the Son, though, in a certain way, also to the Father. Abulafia relates the arrival of the messianic son to the renewal of prophecy, an issue that recurs in Abulafia's works written long before the above passage as it deals with his own mission. What is the logic of the above calculations? In my opinion, Abulafia's cumulative calculations are reminiscent of the Pythagorean secret of the Tetraktys, which is based on the addition of all the numerical values before the last one (the fourth): $1+2+3+4$, which amounts to 10 . This approach was known to Abulafia and we have this type of calculation in the passage translated above: though it is conspicuously built upon a series of gematrias, there can be no doubt that they occur in a sort of crescendo: each unit is followed by another one that is numerically greater. Each later stage is construed as more complex than the previous one and they reflect a particular narrative of some kind: that the three are one unit that should not be disrupted or that the son of David is coming.

However, the ascending numerical valences may reflect a view that is closer to a Pythagorean triangle, which serves as the basis of the calculation of the Tetraktys, a view also found elsewhere in Abulafia's writings. However, if we adopt the Pythagorean mode in order to understand the text, the final sum of the earlier numbers is

135 BT, Yebamot, fol. 63b, or from the Book Bahir. Abulafia interprets these two statements as referring to a secret that would explain the Bahiric theory of the transmigration of the Messiah's soul, although he does not elaborate on how this occurs. See Oșar 'Eden Ganuz, 30-31. I hope to elaborate on this text in my study of the secret of impregnation in Abulafia's writings, where several other texts will also be analysed. 
quintessential: $1+2+3+4=10 .{ }^{136}$ What about the sum of all the numbers mentioned in the text from Oșar 'Eden Ganuz that we translated above: $1+3+52+65+69=190$ ? The need to add those figures is implicit in the addition of the consonants that compound the words whose numerical valences are calculated here. The question is: is this number meaningful in Abraham Abulafia's writings? In the passage translated above, there is no hint of this whatsoever. Nevertheless, in my opinion, the answer is in the affirmative: the number 190 is understood in some of Abulafia's writings as pointing to the end times, as it is "referred" to in the gematria qeș ["end"] = 190 = ne'elam ["hidden"] = penimi ["internal"] = naqam ["revenge"], and which is a date that Abulafia takes to mean 1290, the year he believed would be the time of redemption. ${ }^{137}$

In other words, this is an interesting example of eschatological esotericism, which occurs when the core of the secret is not explicitly specified; we may assume that it was transmitted orally. In my opinion, this is also the case in one of Abulafia's commentaries on a prophetic book where the term ego, which means "I" in Greek and Latin, occurs in the context of his discussion of the knowledge or wisdom of the Messiah, and it is not explicitly explained, but is rather left to the insight of the reader. ${ }^{138}$

What does all this mean? In my opinion, Abulafia's resort to Christian concepts does not betray an attraction to this type of typology. Instead, it is the application of a Pythagorean numerical technique to the various Jewish divine names and the three persons of the Christian triune. He does all of this in order to extract the date of the advent of the Messiah, which he "knew" in advance, since he had already used the gematria in 1282 when he extracted it by means of other kinds of calculations. ${ }^{139}$

136 Much more obvious is his discussion in "We-Zot li-Yehudah," 20, and in parallel discussions, where the four pericopes written in the tefillin are described as amounting to ten. For an analysis of Sefer Yeșirah itself by using Abulafia's text as pointing to the Pythagorean secret of the Tetraktys, see Phineas Mordell, The Origin of Letters and Numerals, According to Sefer Yetzirah (Philadelphia: s.n., 1914, actually Breslau 1914), printed by H. Fleichmann. The text has already been published to a large extent in JQR [NS] 2 (1912): 557-83; 3 (1913): 517-44. Such a view of the phylacteries occurs earlier in Abulafia’s Hayyei ha-Nefeš, 134, which was translated in chapter 26 note 130, chapter 17 note 154 above. See also Idel, “On the Meanings of the Term 'Kabbalah,"” 50-51. See also Wolfson, Abraham Abulafia, 224; unaware of the Pythagorean background, he sees in this text a sign of performance that is related to his more general efforts to infuse some sort of theurgy into Abulafia's Kabbalah. See chapter 5 note 165 and chapter 17 note 146 above. For more on Abulafian texts denying theurgy, see Appendix E and Idel, Middot, chapter 9.

137 Idel, “"The Time of the End," 161-62; cf. Abulafia's 1282 Commentary on Iš Adam, in Mașref haŚekhel, 49, and his Imrei Šefer, 86, written after 1290. See also Moshe Idel, “On Symmetric Histories and Their Termination: On the Prophecy of Rabbi Nehemiah ben Solomon the Prophet” [Hebrew], in Studies in Jewish History Presented to Joseph Hacker, eds. Yaron Ben-Na'eh, Moshe Idel, Jeremy Cohen, and Yosef Kaplan (Jerusalem: Shazar Center, 2013): 111. See also note 276 above.

138 See my Messianic Mystics, 296-301.

139 For the most plausible Ashkenazi sources of Abulafia's gematrias of these words that amount to 190, see the writings of Rabbi Nehemiah ben Solomon, the prophet of Erfurt. Cf. Moshe Idel, "Some 
Is this an influence of Christianity or an exercise in exegetical ingenuity applied to an eschatological secret known in advance as well as to divine names? If the message is understood on the level of hiding a secret as the main message, then the secret itself had nothing to do with the Trinity, but with the messianic date, and, on what he would consider a deeper level, the internal, personal dimension of redemption.

What counts for Abulafia, in my opinion, is the relationship implied by the numerical valences of the words and not the hypostatic status of the three persons of the Trinity. As seen above in the discussion of the myth of the pollution and the removal of the serpent's venom, Abulafia was not entrenched in the worldview of a widespread Rabbinic approach. Though he quoted it, he nevertheless quite openly opposed its main assumptions, just as in the case of his rejection of the micromyth of God's phylacteries, as he discussed in the passage from Hayyei ha-Nefeš translated above. By radicalising Maimonides, Abulafia adopted a much more critical approach towards aspects of Rabbinic micro-myths at the same time that other Kabbalists over-mythicised them.

Abulafia's allegorical approach to Rabbinism, which also has a negative dimension, is also, in my opinion, Abulafia's approach to Christianity: the fact that he interprets some of its concepts does not mean that he was attracted to it, but simply that he decided to apply his radical hermeneutics to it. In this case, the application of the radical exegetical methods, coupled with his eschatological interest, is far more important than the specific contents of the Christian material that he interpreted.

Let us now turn to another triad found in some Kabbalistic texts that have also been understood as being related to Christianity: regarding a passage translated above in the context of the Torah as a median, ${ }^{140}$ we discussed an example of a divergent triad of divine attributes. In the vast majority of the theosophical texts, the sefirah of the right hand, called Gedullah, is identified as Hesed ("mercy"), while its opposite, the left hand, Gevurah, is identified with Din ("the attribute of judgement") or Pahad ("fear"); and the median one, Tif'eret, is conceived as Rahamim ("the attribute of compassion") and is often referred to using the symbols of Šalom and Emet ("truth"). However, according to a fourteenth-century text found in a Hebrew book of polemics against Christianity, a triad of attributes has the attribute of mercy $(=$ Hesed $)$ as the median or preponderating power. ${ }^{141}$ As I have shown elsewhere, different triads of attributes exist in a series of other Hebrew texts, some of

Forlorn Writings of a Forgotten Ashkenazi Prophet: R. Nehemiah ben Shlomo ha-Navi', JQR 96 (2005): 189-90.

140 Or ha-Śekhel, 20. See chapter 10 above.

141 See David Berger, ed., The Jewish-Christian Debate in the High Middle Ages-A Critical Edition of Nizzahon Vetus (Philadelphia: Jewish Publication Society, 1979), 3. 
them contemporary to Abulafia, though the sources may be found much earlier in Jewish texts. ${ }^{142}$

According to Abulafia, there are two attributes that stand as opposites (truth and fear) while the Torah stands between them. Especially interesting in this context is Rabbi Nathan ben Sa'adyah's Ša 'arei Ședeq, where he uses the same designations for the three attributes that occur in other texts that differ from the regular usages of most of the Kabbalists. He speaks about the attribute of compassion (Rahamim), judgement (Din), and a third one, peace (Šalom), which preponderates between the two. ${ }^{143}$ Abulafia's triad of divine attributes differs from that of his student; neither of them is identical to those of other Kabbalists.

This diversity of technical expressions is the reason why I assume the existence of an earlier Jewish source (or sources) that differs from the more common description of the triad of sefirot, a supposition that has recently been proven by additional material discovered by Ronit Meroz in a particular manuscript of the Zohar ${ }^{144}$ as well as by Liebes's analysis. ${ }^{145}$ Abulafia's and Rabbi Nathan's discussions presented here contribute two more instances of triads of divine attributes that differ from the standard one found in theosophical Kabbalah. They open the way towards reinforcing the assumption that the materials I have presented in my studies, those discovered by Meroz, and Liebes's discussions allow for another historical reconstruction of the reliability of the interesting passage found in a later book of Jewish-Christian polemics, where another triad that is divergent in its terminology can be found. ${ }^{146}$ Let me point out that it is quite improbable that the Zoharic text was influenced by Rabbi Solomon ibn Adret's discussions.

Against this background, I would like to address an additional and important discussion that was unknown to me when I wrote my two short remarks on these issues: that of Rabbi Solomon ibn Adret, which was introduced into scholarly discourse by Harvey J. Hames. In two instances in his studies, he claims that ibn Adret's Hebrew passages, which he translated into English and analysed, were influenced by Ramon Llull on a certain point related to the description of the third attribute. ${ }^{147}$

142 See Moshe Idel, "Notes on Medieval Jewish-Christian Polemics" [Hebrew], JSJT 3 (1983/84): 689-98, and Moshe Idel, "More on Middat Hesed" [Hebrew] JSJT 4 (1984/85): 219-22. The first was translated into English in Immanuel 18 (1984): 54-63. See my Middot, chapter 10.

143 See Le Porte della Giustizia, 462, and Liebes, God's Story, 150, note 104. As to the history of the hypostatic entities designated as peace as mediating between two other supernal entities, see Michael Schneider, Scattered Traditions of Jewish Mysticism (Los Angeles: Cherub Press, 2012), 188-91 144 See her "Zoharic Narratives and Their Adaptations," 38-39, 44, note 137, 60.

145 Liebes, God's Story, 123-57. Liebes surmises some Greek possible sources for Philo and for the Midrashic discussions.

146 See Berger, The Jewish-Christian Debate in the High Middle Ages, 3.

147 See Hames, The Art of Conversion, 258-65. Printed in 2000, Hames's discussion in his book could not take advantage of Meroz's study printed in the same year or Liebes's discussions, printed first in 2001, nor could they then have known his argument. However, when elaborating on the same topic in 2009, Hames continued to make the same claim as to the impact of the Llullian vision of the 
Let me present here the most pertinent citation from ibn Adret's discussions, according to Hames's translation:

And as to what the Rabbis said in the Midrash, ${ }^{148}$ that with those three attributes God created the world, [namely] with the attributes of El, Elohim and Yahveh, you should know that there are three attributes: judgement, mercy and a third being a total conjunction [mezugah] of both judgement and mercy [...]. And the name Elohim represents the attribute of complete Judgement. And the name Yahveh, the attribute of complete Mercy. And the name $E l$ is the attribute of total conjunction [mezugah] of both. ${ }^{149}$

On the basis of his translation of the adjective mezugah as pointing to a "total conjunction," Hames claims that ibn Adret was influenced by Ramon Llull, who uses the terms conjunctio and composta in the context of his discussions of the Trinity and calls the powers dignitates. ${ }^{150}$ However, the Hebrew form mezugah does not mean "conjunction," but rather a combination or admixture between two attributes, sometimes envisioned as two types of liquids, one hot and one cold, and its sources are found much earlier in Judaism. They may even be as old as Philo, who utilised a triad of divine attributes throughout his work. ${ }^{151}$ Therefore, there is no special reason to assume that this theme occurs for the first time in ibn Adret's texts or in his master Nahmanides. ${ }^{152}$ He should, according to Hames, be explained as resorting to the theory of an external influence.

Trinity on ibn Adret, although meanwhile more Hebrew material on the three attributes in independent Jewish sources had been revealed and analysed in detail. See his "It Takes Three to Tango: Ramon Llull, Solomon ibn Adret, and Alfonso of Valladolid Debate Trinity," Medieval Encounters 15 (2009): 199-204. I would say that for a real tango, it would be better to invite also another triad: Liebes, Naeh, and Meroz. My following discussions of the three attributes have been translated into Spanish and published in my Estudios sobre la cábala en Cataluña, trans. Javier Guerrero (Barcelona: Alpha Decay, 2016), 23-27. See also now Yair Lorberbaum, “Rabbi Solomon ibn Adret's Treatise against the Christians: A Reevaluation” [Hebrew], Zion 84 (2019): 61-63.

148 The Midrash quoted here is the Midrash Šoher Ṭov on Psalm 50:1.

149 I am essentially following Hames's translation in "It Takes Three to Tango," 201-11, where the original Hebrew sources are also presented. See also Hames, "It Takes Three to Tango," 212.

150 See Hames, 211.

151 Shlomo Naeh, "Poterion en cheiri kyriou: Philo and the Rabbis on the Powers of God and the Mixture in the Cup," in Scripta Classica Israelica 16 [= Studies in Memory of Abraham Wasserstein 2], eds. Hannah M. Cotton, Jonathan J. Price, and David J. Wasserstein (Jerusalem: Jerusalem Academic Press, 1997): 91-101; Liebes, God's Story, 135-57; as well as Haim Hillel Ben-Sasson and Moshe Halbertal, "The Divine Name YHVH and the Measure of Mercy" [Hebrew], in And This is For Yehudah: Studies Presented to Our Friend, Professor Yehuda Liebes, eds. Jonathan Garb, Ronit Meroz, and Maren Niehoff (Jerusalem: Bialik Institute, 2012): 53-69. For the resort to the term memuzag in order to describe the result of the union between a male and female-namely, the offspring, which is related to two equal members of a couple-see Abulafia's Oșar 'Eden Ganuz, 1:3, 140. See also Šomer Mișwah, 28, where he speaks about middot memuzagot. See also Appendix C note 152 below and my Middot, chapter 10.

152 See Nahmanides's discussion of the relations between the divine attributes in his commentary on Leviticus 23:17 as well as in other texts, for example, in a context very close to ibn Adret, in the 
Let me point out in passing that the occurrence of the root $M Z G$ together with the question of the concept of a combination of the divine attributes is found at least twice in Rabbi Menahem Recanati's Commentary on the Torah, written some time at the beginning of the fourteenth century in Italy. ${ }^{153}$ Its contemporary, the anonymous Kabbalistic classic Ma'arekhet ha-Elohut, a book that stems from the circle of Kabbalists around Rabbi Solomon ibn Adret and which was written sometime in the early fourteenth century, describes the sixth sefirah, Tif'eret, as middah mezugah, ${ }^{154}$ combining as it does the two higher sefirot. Though it is not impossible to reduce these two discussions to a common earlier source hypothetically found in ibn Adret's Kabbalistic school, I see it as a much less plausible alternative to my assumption that there were earlier Jewish sources independent of ibn Adret and those influenced by him.

The recurrence of the terms mezugah and mazug in various Kabbalistic contexts is the main reason why, unlike with Hames's hypothesis that ibn Adret's discussions of the three attributes were influenced by Ramon Llull's views on this point, it is much more economical and plausible in my opinion to assume the possibility that the impact went in the reverse direction; whether the Kabbalists influenced Ramon Llull or vice versa. The variety of Hebrew sources from Zoharic material, from early fourteenth-century Spain and Italy and Sicily in the 1280s, some of which even refer to a "Midrash," may more easily be understood as stemming from an earlier common Hebrew source. This means, in my opinion, that Llull's resort to the terms conjunctio and composta may also reflect, as does his doctrine of dignitates, a Jewish Kabbalistic influence. ${ }^{155}$

Moreover, it should be mentioned here that the impact of Nahmanides's theory of several types of kavod (divine glories) on Llull's view of dignitates may be related to the theory of the mixed third sefirah in ibn Adret's discussions because he belonged to Nahmanides's Kabbalistic school. I am not confident that this is indeed the case, since I have not sufficiently studied the topic. However, on the grounds of the available sources as brought forth by Hames, this direction of influence seems to be a more plausible solution. As is known, Ramon Llull was in contact

passage from an anonymous commentary on the Pentateuch related to the school of Abulafia found in Ms. Oxford, Bodleian 1920, fol. 16a that I printed in "Notes of Medieval Jewish-Christian Polemics," 691-92, which resorts to both the Midrash on Psalm 50:1 and to the term mazug in the context of the third attribute; the formulation in the prayer of Šema' Yiśra'el is also found there. If we do not assume that the passage was influenced by ibn Adret, which I do not see to be a necessary assumption, then we may speak of the two authors drawing from a common source, perhaps Nahmanides. For a later resort to memuzag in the context of a third sefirah that mediates between two others, see Rabbi Moses Cordovero in Or Yaqar, vol. 5 (Jerusalem: Ahuzat Yisrael, 1970), 18, as well as 194, 245, and Or Yaqar, vol. 11 (Jerusalem: Ahuzat Yisrael, 1981), 113. See more in my Middot, chapter 10.

153 Commentary to the Torah (Jerusalem: 1961), fols 25d, 66 a.

154 Ma'arekhet ha-Elohut (Mantua: 1558), fol. 86b.

155 See Moshe Idel, "Dignitates and Kavod: Two Theological Concepts in Catalan Mysticism," Studia Luliana 36 (1996): 69-78. 
with ibn Adret, ibn Adret's companion in Barcelona, and Abulafia's former student Rabbi Judah Salmon, who is mentioned above. In my opinion, we may assume in this case that the direction of influence was from Jewish sources to Christian ones, not vice versa. ${ }^{156}$

However, Hames's major point in his article-to show that the addressee of ibn Adret's discussions is to be identified with Ramon Llull-is correct, since it includes a convincing testimony of a certain implicit dialogue between the two contemporary authors, even if the direction of influence is changed. My own view as to the direction of influence is sustained by the fact that Nahmanides, when speaking on the thirteen divine attributes mentioned in Exodus 34:6, was quoted to the effect that the first three terms are the essence of the divine name[s] ('Așmutam) or of the theosophical divinity in general, which he describes as the third, sixth, and tenth sefirah, while the remaining ten terms implicitly refer to the ten sefirot. ${ }^{157}$ Thus, some form of trinity is found in a version of Nahmanides's commentary on the Pentateuch. Moreover, in the context of Nahmanides's view on this point, Rabbi Bahya ben Asher, a disciple of ibn Adret, mentions the term Hesed ("mercy") as being related to the third sefirah of a lower triad, that of Tif'eret, in a manner paralleling some of the triads I have already discussed. ${ }^{158}$

To summarise the discussions in this appendix: the resort to triads and even to triune discussions is not necessarily a matter of Christian influence. In Abulafia's thought, the Aristotelian noetic triad, the triads found in Sefer Yeșirah, and the Midrashic and medieval treatments dealing with three attributes, different as they are from each other, should be recognised as starting points for Abulafia and other Kabbalists' triune discussions, which sometimes attempted to interpret the Christian Trinity. Assuming as I do that these sorts of triads were known to be part of what a Kabbalist would consider the Jewish tradition (the different historical origins of some of them notwithstanding), they could also be used in order to interpret the Christian Trinity, as they do in the case of other topics found in the Jewish traditions. As seen above, triads that include the categories of the senses, imagination, and intellect recur in Abulafia's writings and play a major role in his worldview.

In another Kabbalistic circle that produced short pieces of writing related to Sefer ha- 'Iyyun, three divine lights are conceived as one unit. ${ }^{159}$ In Abulafia's lifetime, triune views can be discerned in the book of the Zohar, as Yehuda Liebes has pointed out. ${ }^{160}$ In this context, the triadic structure of some of the theosophical systems of the ten sefirot should also be mentioned. They are perhaps influenced by Neo-Platonic

156 Idel, "Ramon Lull and Ecstatic Kabbalah."

157 This is a version of Nahmanides’s commentary on Exodus 34:6, as quoted in Rabbi Bahya ben Asher's commentary ad locum that differs from Nahmanides's printed commentary. See Bahya on the Torah, ed. Chaim D. Chavel (Jerusalem: Mossad ha-Rav Kook, 1967), 2:352.

158 See Rabbi Bahyya ben Asher, Bahya on the Torah, 2, and in Appendix C note 142 above.

159 See Scholem, Origins of the Kabbalah, 353-54.

160 Liebes, Studies in the Zohar, 140-45. 
speculations. ${ }^{161}$ However, unlike these Kabbalistic resorts to triads or trinities, in Abulafia's case, there is a dominant triad that was part of his profound structure; the noetic one, which constitutes the main type of his conceptual concerns and which, statistically speaking, is much more widespread than any other trinity.

This means that there was a wide spectrum of triadic speculations found in texts that were dear to Abulafia, one of them emphasising the identification between the three components that could also invite a turn to the Christian triads and not vice versa. Sagerman's monograph on Abulafia's attitude towards Christianity, which insists so much on the importance of triads as part of his view of this Kabbalist's position having been influenced by Christianity, as he repeatedly indicates, neglects the pivotal importance of the non-Christian triads in Abulafia's thought, which I call his profound noetic structure. Therefore, Sagerman's is a one-sided description that belittles the role played by major sources that informed this Kabbalist's worldview. These noetic triads were used as a hermeneutical grid that imposed meanings on a variety of topics, including the Christian Trinity. ${ }^{162}$ Nor have I found in Abulafia's works a tripartite division of the sacred history that is fundamental for the historiosophy of Joachimism, though some sources in late antique Judaism can facilitate its acceptance in his thought. ${ }^{163}$

Let me formulate the problem as I see it in the case of the scholarship dealing with Abulafia and Christianity. The issue is not how much Christianity is actually found in his writings; an issue that should not be denied, but rather dealt with carefully. This issue is about what the nature of scholarship is, and, more specifically, about the philological strength of the proofs adduced in order to prove the presence of Christian themes in his writings. My impression is that with less solid scholarship, it is possible to find many more cases of Christian influence. The more one presents all the pertinent evidence and analyses it in detail, the more difficult it is to express interesting generalisations and to learn, for example, about Abulafia's alleged fears of castration, about his concept of the great mother, and similar clichés.

However, to be clear, this simplistic approach is the case not only in scholarship on Abulafia, but also with some of the other instances of scholars attempting to prove Christian influences on early Jewish mysticism ${ }^{164}$ and medieval Kabbalah ${ }^{165}$

161 Whether Abulafia was acquainted with triadic speculations in Neo-Platonic metaphysics or not is an open question. See Chapter 6 note 221 above. On the Neoplatonic trinity and Christianity, see the detailed analysis by Paul Aubin, Plotin et le christianisme (Paris: Beauchesne, 1992).

162 See The Serpent Kills, viii.

163 Whether or not the tripartite distinction between three periods of two thousand years each found in earlier Jewish and Christian sources is influenced by Joachimism is a matter that deserves a separate investigation. See Bernard McGinn, The Calabrian Abbot: Joachim of Fiore in the History of Western Thought (New York: Macmillan, 1985), 161-92; for earlier Jewish sources, see Pedaya, Nahmanides: Cyclical Time and Holy Text, 16, 38, note 24.

164 For the strong penchant in this direction in the recent studies by Peter Schäfer, see The Origins of Jewish Mysticism (Princeton: Princeton University Press, 2009), especially 32-33. See also Ra'anan S. Boustan, From Martyr to Mystic: Rabbinic Martyrology and the Making of the Merkavah Mysticism (Tü- 
in a more generalised manner. Though certainly not entirely absent, in my opinion, these influences have been greatly exaggerated in recent scholarship. The scant amount of evidence to this effect is quite obvious when we compare the plethora of evidence we have as to the presence of philosophical influences (such as Neo-Aristotelian, Neo-Platonist, and even Hermetical ones), to say nothing of the astronomical-astrological influences, in the various writings of the Kabbalists of the thirteenth century. ${ }^{166}$

By neglecting (and in some cases even completely ignoring) the formative impact of the obvious sources, mainly the philosophical ones that constitute the profound structure of Abulafia's thought, by not discussing pertinent passages written by him on a topic under scrutiny in all their occurrences and thus not carefully weighing their impact, and by ignoring the specific meaning of crucial terms like the specific Tibbonian use of the term meyuhad, some scholars have discovered "subtle" themes that they consider to be psychological, theurgical, theosophical, Sufi, or Christian, and which again were deemed to be clues for decoding Abulafia's vaguer remarks. In most cases, these are misunderstandings because they are based on misinterpreted passages, sometimes understood inversely to their actual meaning; at the same time, they ignore other pertinent texts explicating the Kabbalist's intention in an explicit manner, as we have seen in several instances discussed above.

I have attempted to analyse some of these problems, not just by pointing to the weakness of the recent interpretations offered by scholars, but also by proposing my more general alternative interpretation based on a broader series of texts, sometimes

bingen: Mohr Siebeck, 2005) and some of the studies in Adam H. Becker and Annette Yoshiko Reed, eds., The Ways That Never Parted: Jews and Christians in Late Antiquity and the Early Middle Ages (Minneapolis: Fortress Press, 2007). For early Rabbinic Judaism and early Christianity, see the earlier view of Daniel Boyarin, Dying for God: Martyrdom and the Making of Christianity and Judaism (Palo Alto: Stanford University Press, 1999) and Daniel Boyarin, Border Lines: The Partition of Judaeo-Christianity (Philadelphia: Pennsylvania University Press, 2004). A more nuanced view is found recently in Daniel Boyarin, "Beyond Judaisms: Metatron and the Divine Polymorphy in Ancient Judaism," Journal of Studies of Judaism 41 (2010): 323-65. These Christotropic approaches do not take into consideration a variety of additional sources, such as the Iranian or Pagan Greek/Hellenistic backgrounds. See also Appendix D note 215 below.

165 This is the view of Arthur Green and Peter Schäfer. For my great doubts about their claims as to the influence of the Marian cult in Christianity on the feminine perception of the Šekhinah in Kabbalah, see my Kabbalah and Eros, 46-47, 268, note 143; Idel, Ben, 377-403; and more recently, on the grounds of additional texts not previously taken into consideration, Moshe Idel, "The Family Aspects of Divinity in Early Kabbalah" [Hebrew], in Tov Elem: Memory, Community \& Gender in Medieval \& Early Modern Jewish Societies, Essays in Honor of Robert Bonfil, eds. Elisheva Baumgarten, Amnon Raz-Krakotzkin, and Roni Weinstein (Jerusalem: Mossad Bialik, 2011): 91-110, and Yehuda Liebes, “Was the Šekhinah a Virgin?” [Hebrew], Pe'amin 101-2 (2005): 303-13. Based on general and often anachronistic reflections without pointing out any specific textual borrowings, this theory reflects more the modern situation of a Jewish-Christian dialogue than events in medieval history.

166 See Idel, "Jewish Kabbalah and Platonism in the Middle Ages and Renaissance” and Idel, "Hermeticism and Kabbalah.” 
unknown to or neglected by those scholars even though I demarcated them in some of my earlier studies. It would be more helpful if a full perusal of Abulafia's extant writings and those written by his school constituted a basic scholarly requirement for engaging with his complex thought. Such a perusal is far from obvious from reading most of the studies that have recently been published.

Secondary sources, like the earlier studies of Abulafia from the mid-nineteenth century, are only rarely mentioned by a few of these scholars and sometimes, when mentioned at all, their meaning is distorted, as we have seen above. Only when a more mature, erudite, and critical approach to the pertinent sources and the entire range of scholarship on the topic takes shape will a more solid and comprehensive picture of Abulafia's thought and its specific features emerge, whether it be similar to what I described above or different. By relying on a sometimes inverted presentation of Abulafia's thought, it is difficult to offer a significant psychological interpretation. Only when this new approach to Abulafia studies prevails may psychological speculations help, perhaps, but they do so very little otherwise.

\section{Appendix D: From Patras to Rome: Annus Mirabilis 1279/80}

I have attempted in this book to delineate some of the major moments in Abulafia's intellectual life, especially those relating to his study of philosophy and his esotericism. In this appendix, I shall try to briefly describe one of the most intense periods in his life, 1279/80, which was both, roughly speaking, the fortieth year of Abulafia's life as well as the fortieth year of the sixth millennium of the Jewish calendar. ${ }^{167}$ Many of the above discussions have constituted interpretations of some passages from Abulafia's Or ha-Śekhel. This book is part of an unusually febrile literary activity spanning between the beginning of 1279 and the end of 1282, which is the period when he committed to writing Sitrei Torah, Hayyei ha-'Olam ha-Ba', Or ha-Śekhel, his first eight prophetic writings, and their commentaries, to enumerate only the books that explicitly carry dates from this period.

This flow of great profusion has to do with two different though not independent reasons: one is his turning forty, considered to be the time of intellectual maturity or the reception of wisdom according to some Jewish traditions that Abulafia explicitly referenced, ${ }^{168}$ and the other is that this was the time determined in his 1270/71 revelation that he should go to Rome. ${ }^{169}$ Another important revelation from the point

167 I draw here from my study "The Kabbalah in Byzantium: Preliminary Remarks," in Jews in Byzantium; Dialectics of Minority and Majority Cultures, eds. Robert Bonfil, Oded Irshai, Guy G. Stroumsa, and Rina Talgam (Leiden: Brill, 2012): 665-79. I would like to correct the date of Abulafia's arrival in Patras from 1278-as mentioned in 675-to 1274, as explained here below.

168 See my "On the History of the Interdiction" and "Abraham Abulafia: A Kabbalist 'Son of God,"” 77.

169 See Commentary on Sefer ha-'Edut, in Mașref ha-Śekhel, 57. 
of view of Abulafia's output that took place in 1279 in Patras or in the Byzantine Empire probably reiterated the earlier demand to go to Rome, as we shall see below in this appendix. ${ }^{170}$ These facts meant not just a sudden intensification of his literary activity in 1279/80 and immediately afterwards, but also his turn to two new literary genres: prophetic books, which by his own account he began in 1279, and handbooks for reaching mystical experiences, which possess salvific overtones and which were intended to teach others how to reach the experiences found in the first new literary genre.

Indeed, the two handbooks Hayyei ha- 'Olam ha-Ba' and Or ha-Śekhel, Abulafia's two most widespread technical treatises amongst all his writings (in manuscripts), were written in this period. They primarily deal with the details of his methods and were designed so that they could assist potential aspirants to reach what he considered to be sublime experiences through initiating a certain type of experiment. This was also the same year that he wrote the third and perhaps the last of his three commentaries on the secrets found in Maimonides's Guide: the influential Sitrei Torah. In any case, a comparison of Abulafia's literary production in the decade before $1279 / 80$ to what he wrote during the decade afterwards shows that he dramatically intensified his writings, but even then, his literary creativity of the three years mentioned above is unparalleled in its breadth and originality.

In other words, these three years constitute a turning point in Abulafia's messianic activity, grounded in the belief that he could disseminate a sort of knowledge that could assist other people to reach a spiritual experience independently of his personality or his presence in a certain place. Nevertheless, unlike the intense personality cult that surrounds messianic phenomena like the magnetic late antique figure Rabbi Simon bar Yochai, so characteristic of the Zoharic imaginaire, and, later on, of many other Kabbalists, in Abulafia's case, it is the individual's noetic processes that are presented as the clue for his eschatological aspiration, and we have discussed above the issue of individual versus collective experience in Abulafia's work.

Let me analyse now an important passage dealing with a revelation that Abulafia claims to have had:

Afterwards, Razi' $\mathrm{el}^{171}$ saw a vision, within which he comprehended the secret of the [divine] name, and the secret of prophecy, and the essence of its truth. And he said that at the time of the fifth [year] since his coming to Dibon, which was the sixth year since his departure from Sefarad, in the tenth [month], which is the month of Tevet, on the fifth day [of it], behold, he revealed the secret of the name. Also ${ }^{172}$ Patros [is] Sefarot [is] Šemot. ${ }^{173}$

170 Commentary on Sefer ha- 'Edut, in Mașref ha-Śekhel, 57.

171 Razi'el $=$ Avraham $=248$. The name Razi'el, which means "the secrets of God," recurs dozens of times in his early prophetic books.

172 Hames, Like Angels on Jacob's Ladder, 40, skipped the following four crucial words and interpreted the whole story as if it were related to Sicily, part of his working hypothesis as to the importance of the 1270s for Abulafia's encounter with the Joachimite Franciscans. On this issue, see more below in this appendix. 
Let me first address the conceptual structure of the passage. Though mentioning a vision, Abulafia does not describe its details or the visual aspects of it, but reports only what he understood; namely, what he comprehended from it, most probably what he decoded. That the figurative details of the vision were already in the original version of the prophetic book that has not survived and that the interpretation is part of the commentary on the book are plausible, but not certain.

I assume that this is an example of a self-interpretation of a brief narrative that is similar to the parable of the pearl according to terms that belong to the third narrative. Abulafia's understanding of the content of the vision is conveyed using a verb that displays a conspicuously philosophical act: hisig ("he comprehended"). This act is related to understanding secrets, which means that what he saw in the vision was believed to be a coded message that possessed a secret dimension that was waiting to be deciphered. From this point of view, his vision is to be understood in a similar way to how he regarded the prophetic texts in the Bible, which he also thought had more than one sense, in a manner reminiscent of Dante's claim in his famous letter to Cangrande. ${ }^{174}$

This passage deals with a crucial detail in Abulafia's biography: we learn from it that he arrived at a place named Dibon five years before the vision. This means that he was still living in Dibon when he wrote the passage. This vision is found in his first prophetic book, Sefer ha-Yašar, which was written in Patras in the month of November or a short time later in the year 1278, according to the testimony found in Sefer ha-'Edut, another prophetic book. ${ }^{175}$

A stay in the same place (Dibon) for five probably consecutive years is a relatively long period of sojourn in Abulafia's intensely itinerant life. Immediately beforehand, he had been wandering for approximately a year after leaving Sefarad, which, in the terminology of his generation, refers to one of the provinces of modern central and northern Spain. Thus, in 1278, we are at the end of his stay in Dibon, since Abulafia's last departure from Spain took place six years earlier in late 1273, as we discussed in chapter 5 above. This means, as he explicitly puts it, that he left Spain (not Barcelona, as Hames claims and then calculates his timetable on this basis), ${ }^{176}$ and for an entire year or so roamed the Greek towns of Thebes and Eurypo. He then arrived

173 Commentary on Sefer ha-Yašar, in Mașref ha-Śekhel, 99:

אחרי כן ראה רזיאל מראה שבה השיג סוד השם וסוד הנבואה ומהות אמתתה. ואמר שבזמן ה' לבואו לדיבון אשר היא שנת ו' לצאתו מספרד ב"י שהוא החדש הנקרא טבת בה' ימרים בו הרי הרי גלה סוד השם. גם פתרוס ספרות שמות.

The $\mathrm{H}$ = five, $\mathrm{W}$ = six, $\mathrm{Y}=$ ten, and $\mathrm{H}$ = five represent the consonants of the Tetragrammaton. This is a strategy found elsewhere in Abulafia's dating of his revelations by resorting to letters of divine names. For a different interpretation of the meaning of this passage, see Hames, Like Angels on Jacob's Ladder, 40. It is possible that Abulafia was here working on the alliteration of Sefarad and Sefarot.

174 See also Idel, “On Symbolic Self-Interpretations in Thirteenth-Century Jewish Writings.”

175 Commentary on Sefer ha-'Edut, in Mașref ha-Śekhel, 57.

176 Hames, Like Angels on Jacob's Ladder, 40. See, however, the Commentary on Sefer ha-'Edut, in Mașref ha-Śekhel, 57 (originally written in 1280), where he speaks about this year as the tenth year since he had the revelation in Barcelona. 
in Patras and remained there for approximately five years, either consecutive or not. $^{177}$

In my opinion, this understanding of the details of Abulafia's biography means that Patras should be identified with the name Dibon, though I do not understand exactly why he used the name of the biblical town in this context. ${ }^{178}$ One possible explanation would be that the consonants of Dibon amount in gematria to 72 , like the so-called divine name of seventy-two letters that was very important for Abulafia in general, especially in that period, as is clear from his Hayyei ha- 'Olam ha-Ba', just as he identifies Patras, spelt Patros in Hebrew, with Šemot (names) because the two words, like Sefarot (numbers), amount in gematria to 746. Later in the same book, he describes Har Patros ("the mountain of Patros") as being composed of the same consonants as the phrase Sefer Torah and thus also sharing the same gematria of $991 .{ }^{179}$

In fact, I see no reason to assume that Abulafia would speak about one town in Greece and another in Sicily in the same paragraph without hinting that they were two different localities or at his transition from one to the other. In my opinion, it is very plausible that while the name Patros stands for the positive attitude towards Abulafia, Dibon, or Dibona, stands for the negative attitude towards him, as he probably understood it as being derived from the Hebrew word Dibbah, which can be translated as "defamation" or "slander." These two different attitudes are explicitly mentioned in the immediate context of the passage from Sefer ha-Yašar that was translated in the previous paragraph. ${ }^{180}$

However, Hames attempts-so I understand him-to dissociate the time of the writing of the first prophetic book, Sefer ha-Yašar, written at the beginning of 1279, from the time when the vision mentioned in this book took place, which, according to him, occurred several years earlier somewhere in Sicily in $1276 .{ }^{181}$ However, based on the evidence we have, this chronology is rather impossible, since 1276 fell during the six years of his sojourn in the Byzantine Empire, which occurred after he left Sefarad-Castile or Spain-probably as late as 1273 or perhaps early 1274 .

In my opinion, Abulafia left Barcelona sometime at the end of 1271 and Sefarad in 1273/74; these are two different events that should not be confused. There is there-

177 We may speculate as to the reason for such a long stay in one city which was not very important in Jewish life by assuming that he married his wife there fourteen years earlier when on the way from searching for the legendary river of Sambatyon, where the ten lost tribes were imagined to be hiding, or on his way back in both cases in 1260. As it was an important port, Abulafia could have stayed in Patras, then a territory belonging to Venice, for a while and have married either on his way eastward or when returning to Europe, and his return fourteen years later might have been a prolonged family visit. If my hypothesis as to the messianic valence of the year 1280 is true, it may be that he left his family in Patras and travelled to Italy alone, confident as he may have been of the imminence of a change in history, according to the second narrative mentioned above.

178 See Numbers 21:30, 32:34, or Joshua 13:9, 17.

179 Commentary on Sefer ha-Yašar, in Mașref ha-Śekhel, 98.

180 Commentary on Sefer ha-Yašar, in Mașref ha-Śekhel, 97-98.

181 Hames, Like Angels on Jacob's Ladder, 31, 40-42, 71, 125-26, note 47. 
fore no evidence and, in my opinion, no reasonable need to substantially disassociate the date of the composition of Sefer ha-Yašar from the date of the vision reported in it, and it is quite plausible that they both took place sometime in late 1278, in the same town (Patras), or at least for the writing of the book in early $1279 .{ }^{182}$ To the best of my knowledge, there is no extant evidence of any visions Abulafia had after 1270/ 71, after the Barcelona revelation and before late 1278.

This chronology means that it is quite plausible that during the six years between Abulafia's departure from Spain and his second visit to Italy, first to Trani or Terni and then to Capua in 1279, he spent most of the time, if not all those years, in the Peloponnese part of the Byzantine Empire and in Patras, then a colony of Venice, where he taught The Guide of the Perplexed according to his special method. Let me repeat, no solid indication is available in the material with which I am acquainted as to an important revelation, or any revelation at all, that occurred in 1276, as alleged by Hames. If my historical reconstruction is correct, there scarcely remains the necessary time for a significant visit to Italy or Sicily between the years 1269 and 1278, if such an early visit or stay took place at all, as assumed by Hames for the sake of his attribution of the alleged Franciscan-Joachimite influence on the ecstatic Kabbalist. ${ }^{183}$ In any case, I know of no evidence of such a visit to the island any time before late 1280 or early 1281 .

The implication of this timetable is that after turning from the study of philosophy to the study of Kabbalah in 1270, Abulafia spent a significant period of time in a religious milieu dominated by Christian Orthodoxy-its well-known presence was also felt in southern Italy and in Sicily, where Abulafia visited and stayed for longer periods. Hence, the possible influence on Abulafia's thought of a Christian form of mysticism known as Hesychasm, which intensified its impact in monasteries in Mount Athos towards the end of the thirteenth century, becomes quite plausible, at least in the case of some of the details of his techniques. ${ }^{184}$ Moreover, the recurrence of many Greek words in Abulafia's writings-which, I would say, are as numerous as the Latin/Italian ones-mitigates in favour of a greater role played by Orthodox Christianity than has been recognised in the more recent surveys on Abulafia and Christianity.

It should be mentioned that in 1279/80, Abulafia had an additional revelation in Capua, where he claims that he was told what would happen to him in Rome some months or weeks later. ${ }^{185}$ This proleptic revelation shows that the historical register was important at this stage, though it was certainly not the most important one. In the summer of 1280, he experienced a third revelation, either in Rome or in Soriano nel Cimino (a small town north of Rome where the pope sojourned for several weeks

182 Let me point out that though it is plausible that he also taught the Guide in this town, as Hames indicates (42), we have no textual evidence for this.

183 Hames, Like Angels on Jacob's Ladder, 125-26, note 47.

184 Idel, The Mystical Experience, 13, 24, 35, 40, 80, 122, 176-77, note 338.

185 See Commentary on Sefer ha-Hayyim, in Mașref ha-Śekhel, 79. 
from the beginning of July), whose content is included, I assume in a fragmentary manner, in the Commentary on Sefer ha- ${ }^{\text {Ed }}$ dut. ${ }^{186}$

A few months later, Abulafia had two other revelations in two consecutive days. ${ }^{187}$ This means that in a year and a half, he had at least five revelations mainly related to the divine name and his wish to meet the pope. In his prophetic books written in this period, he speaks about additional visions, as many as ten, in the manner in which Ezekiel's visions are understood. ${ }^{188}$ Given their very cryptic language, with many unexplained allusions and a discourse that is unparalleled by any other Kabbalistic text with which I am acquainted, only a very small number of passages from these revelations and their commentaries have been analysed in scholarship so far, though many of them most probably touch major issues in Abulafia's prophetic and messianic self-perception as well as his biography. ${ }^{189}$

The period between the last two months of 1278 and the second part of 1280 roughly corresponds to the fortieth year of Abulafia's life, the year when the emergence of the intellect was considered to occur and which had personally redemptive implications as seen above in chapter 20. We cannot, however, ignore an additional possible interpretation of this fact as a reference to the supposed appearance of the Messiah during the year 5040. ${ }^{190}$ The meeting with the pope was intended-at least in Nahmanides's version, which is the most plausible source for our knowledge of Abulafia's attempt-to be the act of the Messiah, as Nahmanides mentions twice in his polemic with Pablo Christiani. ${ }^{191}$

Indeed, in Abulafia's prophetic books, the messianic theme is incomparably more conspicuous than in his writings from before 1279, and even more than in most of his later books. ${ }^{192}$ We may speak about a concentration of discussions on this topic that reverberates only in his much later prophetic book Sefer ha-Ot.

186 Sefer ha-'Edut, 57.

187 Sefer ha-'Edut, 58.

188 Sefer ha-'Edut, 61, and Sefer ha-Yašar, 99.

189 See Idel, The Mystical Experience, 126-28; Idel, Messianic Mystics, 73-74, 82-83, 295-307. On the cryptic nature of some books that the teacher of Rabbi Nathan Har'ar (Abulafia) had shown to him, see Le Porte della Giustizia, 478. It should be pointed out that Abulafia claimed to have written more books of this type (twenty-two prophetic books) and it seems that only one more has survived, Sefer ha-Ot, in addition to the 1279-80 books, upon which he wrote commentaries. For the figure of the twenty-two prophetic books mentioned by Abulafia, see "Ševa' Netivot ha-Torah," 23. To this literary genre also belongs, in my opinion, the lengthy fragment referred to as the Untitled Treatise that has been mentioned several times above, which survives anonymously in a unique manuscript, Ms. Firenze, Laurenziana, Plut. II. 48. See also Krawczyk, Księga Znaku: Rabbi Abraham Abulafia.

190 I draw here from some of the arguments printed in my article "Abraham Abulafia and the Pope." 191 See the Hebrew account of Nahmanides's polemic with the convert to Christianity Pablo Christiani, where the former asserted that the Messiah would go to the pope. See Kitvei ha-Ramban, 1:306. That this text had an impact on Abulafia's intention to speak with the pope was pointed out by Abba Hillel Silver, A History of Messianic Speculation in Israel (New York: Macmillan, 1927), 146; Scholem, Major Trends in Jewish Mysticism, 128; and Scholem, The Kabbalah of Sefer ha-Temunah, 113-14. 192 See Idel, Messianic Mystics, 235-307. 
Thus, the year 1280, which comprised the last months of the Hebrew year 5040 and the first eight months of 5041, would, in Abulafia's eyes, have been a messianic year, which he later postponed to the year 1290/91. ${ }^{193}$ In this context, let me point out that in the book of the Zohar, there is a discussion about a Messiah who goes to the pope at a certain moment that is quite reminiscent in some of the details of Abulafia's episode, as Adolph Jellinek already pointed out more than a century and a half ago. ${ }^{194}$

Let me turn to the fact that 1280 was the fortieth year of Abulafia's life. In this context, I will mention an interesting testimony that reports an eschatological expectation for the fortieth year. In a letter by the Franciscan author Roger Bacon (known as doctor mirabilis) addressed to Pope Clement IV, who was his protector, during the year 1267/68, he writes: "But it was stated in a prophecy forty years ago, ${ }^{195}$ and in this regard there are many corroborating visions, that the pope that will be during this time ${ }^{196}$ will purify the canon law and the Church of God of railleries and of frauds of justice, and will enact justice for all, without the din of controversy." 197 Moreover, according to Bacon, that future pope will "renew the world and convert many Gentile nations (to Christianity) and the remnant of Israel will change their faith (to Christianity)."198

As Marjorie Reeves has proposed, in these texts, there is evidence of a clear influence from Joachim da Fiore; ${ }^{199}$ yet I have found no explanation whatsoever in her analysis or elsewhere for the meaning of the quite vague reference to "the fortieth year" when the ideal pope was to appear or to perform his eschatological acts. Are we permitted here to entertain the possibility of an influence from a motif found in earlier Jewish thought that stipulated the arrival of the Redeemer during the fortieth year since 1240, which was the beginning of the sixth millennium and, according to the Jewish calendar, 5000; namely, 1280? Was the future pope, who was perceived as a figure who would cause the nations to convert to Christianity

193 See already Idel, 83-84.

194 See Idel, 121-24.

195 The Latin phrase a quadraginta annis is not entirely clear. I have cautiously translated that the original prophecy was dated forty years ago, but it is also possible that it means that in the year forty; that is, something will happen in the fortieth year since the prophecy.

196 Namely, forty years later.

197 Roger Bacon, “Opus Tertium,” in Opera Inedita, ed. John S. Brewer, vol. 1 (London: Longman Green, 1859), 86, cited in Marjorie Reeves, The Influence of Prophecy in the Later Middle Ages: A Study in Joachimism (Notre Dame: University of Notre Dame Press, 1993), 47: "Sed prophetatum est a quadraginta annis, et multorum visiones habitae sunt, quod unus Papa erit his temporibus qui purgabit jus canonicum et ecclesiam Dei a cavillationibus et fraudibus juristarum et fiet justitia universaliter sine strepitu litis." See also Bernard McGinn, "Pastor Angelicus," in his Apocalypticism in the Western Tradition (Aldershot: Variorum, 1994), 6:227-28.

198 Roger Bacon, “Opus Tertium," 47: "Renovetur mundus et intret plenitudo gentium et reliquiae Israel ad fidem convertantur.”

199 Reeves, The Influence of Prophecy, 46-49. 
in the fortieth year, reflecting a theme originally stemming from a Judaic messianic tradition that was later made consistent with Christianity?

It is worth noting that Roger Bacon mentions that the prophecy and the visions foresaw the arrival of some form of angelic pope forty years later ${ }^{200}$ and that this detail was most probably also a component in Abulafia's 1270 vision in Barcelona that was, hypothetically speaking, about 1280, the fortieth year after 1240. In other words, the fact that two different eschatological traditions related to visions and prophecies, two apocalypses, Bacon's and Abulafia's, overlap in terms of the relationship between some form of redemptive action in the fortieth year by dint of a prophecy that is not otherwise accounted for may point to a hypothetical Jewish source that influenced both prophets independently. To be sure: forty is a well-known formulaic number in Jewish culture in general, but what is especially pertinent is the fact that in some Jewish messianic texts, it reflects a correspondence to the forty years of the Israelites' wandering in the desert: beginning with redemption, understood as the Exodus from Egypt, and the end of the process being the entrance into the Land of Israel.

Since the possibility of Abulafia's influence on Bacon can be safely excluded, and in my opinion also vice versa, I opt for the existence of a common source, or sources, reminiscent of what is found in some earlier Jewish sources. ${ }^{201}$ In this framework, I cannot enter into the complex question of the possible Jewish sources or even into the hypothesis of a possible Jewish background of Joachim da Fiore; however, on the grounds of the most recent scholarship in the field, this line of investigation should not be ignored, especially when dealing with his possible impact on Jewish thought. ${ }^{202}$ This means that there is a possibility that common sources, found in Judaism in Europe in the twelfth century or earlier, may have been shared by both the famous abbot of Calabria and Abulafia.

In any case, the ecstatic Kabbalist's thought can be better understood against the background of two eschatological traditions found separately in two of Nahmani-

200 Reeves, 48, note 1.

201 Regarding the coming of the Messiah of the House of David forty years after the arrival of the Messiah of the House of Joseph, see the late antique Hekhalot Rabbati, chapters 37 and 39, according to Shlomo A. Wertheimer, ed., Batei Midrašot (Jerusalem: Mossad ha-Rav Kook, 1968), 1:125, 130, or Midrash Tanhuma', pericope 'eqev, par. 7. See also Nahmanides's Sefer ha-Ge'ulah, printed in Kitvei Ha-Ramban, 1:291, 294. See also Appendix D note 191 above.

202 See, especially, Robert E. Lerner, The Feast of Abraham: Medieval Millenarians and the Jews (Philadelphia: University of Pennsylvania Press, 2001), who went quite significantly beyond the more general remarks on Joachim's acquaintance with Jewish themes as proposed by Marjorie Reeves and Beatrice Hirsch-Reich, The Figurae of Joachim of Fiore (Oxford: Clarendon Press, 1972), 40-43, 173, note 14; Beatrice Hirsch-Reich, "Joachim von Fiore und das Judentums," in Judentum im Mittelalter, eds. Paul Wilpert and Willehad P. Eckert (Berlin: De Gruyter, 1966): 226-63; Beatrice Hirsch-Reich, “Die Quelle der Trinitaetskreise v. Joachim von Fiore und Dante,” Sophia 22 (1954): 170-78; McGinn, The Calabrian Abbot, 170-71; and Idel, “Abraham Abulafia’s Works and Doctrine,” 134. See also Appendix C note 163 above. 
des's writings, which were not influenced by Bacon or Joachim..$^{203}$ Few and sometimes only implicit as those possible Jewish sources of Joachim's thought are, even according to the scholars mentioned in one of the last two footnotes, they are nevertheless more concrete and more compelling than the details of Joachimite or Franciscan material that have been referred to as part of the hypothesis of their influence on Abulafia. ${ }^{204}$

If this hypothesis is correct-namely, that a Jewish tradition existed that predicted the time of the arrival of the Messiah, or of an eschatological event, reminiscent of the prophecy mentioned by Roger Bacon, that would take place during the year 40, or, according to another possibility, in Abulafia's 1270/5030 revelation in Barcelona, in 1280/5040-it is understandable why Abulafia insisted, at any price, on holding his meeting with the pope before the end of the Jewish year, in August 5040. That was also the fortieth year of his life and he was determined to meet the pope "on the eve of the New Year" ${ }^{205}$ as part of his first messianic date, the year 5040. Since we do not have the original versions of Abulafia's prophetic books, which can be guessed to be rather incomprehensible from the few quotations found in his commentaries, and we only have his commentaries written after 1280 , it is difficult to know more about the centrality of this year in the interpretations he offered after the fact.

Let me point out that in his prophetic books and their commentaries written between 1279 and 1282, Abulafia mentions several times that he is aged forty. ${ }^{206}$ After all, he calculated the special gematria of the words arbba'im šanah ["forty years"] = 'oneš ha-eivarim ["the punishment of the limbs"] ${ }^{207}=678=$ Razi'el $^{208}$ ben Šmu'el. ${ }^{209}$ The latter refers to Abulafia's forename, Abraham, and to the name of his father, respectively. Does such a gematria mean that the quintessence of the name Abulafia is

203 See Appendix D notes 191 and 201 above.

204 For the possibility that another important thirteenth-century Christian apocalypse, the widespread Latin Tripoli prophecy, may display some form of Jewish influence, see Idel, "Mongol Invasions and Astrology," 150-53. On this apocalypse, see the comprehensive monograph by Robert E. Lerner, The Power of Prophecy: The Cedar of Lebanon Vision from the Mongol Onslaught to the Dawn of the Enlightenment (Berkeley, Los Angeles: University of California Press, 1983).

205 Commentary on Sefer ha-'Edut, in Mașref ha-Śekhel, 57: ביום ערובה של ראש השנה. In print, there is a mistake: ערובה for for also the tradition that the Messiah will come on the 28th day of the month of Elul, very close to the eve of the Jewish New Year, discussed in Idel, "Abulafia and the Pope," in Chapters in Ecstatic Kabbalah, 62. On the affinity between New Year and redemption, see my Messianic Mystics, 82-84, and, for its wider context, 21, 45, 213, 220, 246, 289.

206 See, e.g., commentaries on Sefer ha-'Edut, 75, Sefer ha-Hayyim, 79, 82, 83, or Sefer ha-Haftarah, 111, all printed in Mașref ha-Śekhel.

207 While the concept of forty years, dealing with a precise moment in history, is part of what I earlier called Abulafia's second narrative that deals with events in history, the birth of the intellect in that year and the punishment of the limbs belong to his third narrative or register.

208 Razi'el $=248=$ Avraham.

209 Commentary on Sefer ha-Hayyim, in Mașref ha-Śekhel, 83. This form of reference occurs in the same period in his Sitrei Torah, 17, but only extraordinarily rarely later on. 
understood in terms of the secrets of God-this is, the meaning of the angelic name Razi'el, which is numerically identical to Abraham-or Šmu'el, which can be interpreted in Hebrew as the name of God as well as the age of forty? I can hardly imagine another more plausible interpretation for this outstanding gematria. The "punishment of the limbs" may quite plausibly refer to the preponderance of the spiritual over the corporeal organs. This punishment is related to the knowledge of the names of God.

In other words, though traditions dealing with a variety of eschatological topics were known from different kinds of sources, the round decades in Abulafia's life (1240: the year of his birth; 1260: the year of his search for the Sambation river; 1270: the year of his messianic revelation in Barcelona; 1280: the year of the revelations mentioned above and his attempt to meet the pope as part of a messianic date; and finally 1290: the year of his postponed date) are a timetable that is more decisive for the manner in which he interpreted the eschatological process. ${ }^{210}$ Though some of the earlier dates could only be retroactively significant for Abulafia, it is difficult to escape the impression that the rhythm of a chronology of round decades played a role in his understanding of eschatology.

In general, my approach to complex inter-religious affinities that are not openly recognised by the authors themselves or that are not textually proven by a serious analysis, but are only conjectural and based solely on the existence of common themes in similar contexts, is quite cautious. Many of the suggestions in this direction stem from preconceived scholarly assumptions that are at base historicistic. There are plenty of reasons to doubt many of them, and parallels can also be explained by similar, though unrelated, developments. For example, when dealing with the similarity between Abulafia's emphasis on the centrality of the name of God in his Kabbalah and the nascent cult of the name of Jesus in the Franciscan camp in the first part of the thirteenth century (and, later in Abulafia's generation, among some Dominicans as well), I have not attempted to derive one of these tendencies from the other, but I rather assume the possibility that Abulafia's awareness of such a cult in Christianity could facilitate his propaganda of the centrality of the divine name stemming from earlier Jewish traditions that are also known in Christian circles. $^{211}$

210 For more on this issue, see Idel, Messianic Mystics, 97-100.

211 See "Abulafia and the Pope," in my Chapters in Ecstatic Kabbalah, 69-70, where I referred to the seminal work of Peter R. Biasiotto, History of the Development of Devotion to the Holy Name (New York: St. Bonaventura College and Seminary, 1943), 69-71, or to the later phenomenon, in the fifteenth century, as discussed by Loman McAodha, "The Holy Name in the Preaching of St. Bernardine of Siena," Franciscan Studies 29 (1969): 42-58, an interesting issue not dealt with by Hames and Sagerman. Also, Pope Gregory X (1271-76), who served at the Holy See before Nicholas III, the pope whom Abulafia tried to meet, had recommended some form of devotion to the Holy Name, understood as the name of Jesus. 
My assumption as to the existence of a wider spectrum of Jewish traditions that should be taken into consideration for understanding Abulafia informs my general approach $^{212}$ and is the reason for my claim in one of my studies that the Joachimite influence on Abulafia was marginal, if present at all. Evidently, I have not closed the door to such a possibility there, provided that new texts are discovered that may teach us something different. ${ }^{213}$ However, in my opinion, no such new text has been introduced into scholarly discussion that was unknown when I wrote what I wrote, nor have the known texts been analysed in a convincing manner, apart from interesting suggestions that are based on conjectures or contextual possibilities grounded in concomitance of time and place. This hypothesis that there was an impact of Joachimite spirituality on Abulafia is, in my opinion, a suggestive proposal that should, for the time being, not be considered a solid starting point for further speculations. However, a serious scholar should keep this possibility in mind while refraining from building further conclusions upon it.

Let me remind the reader that at least in principle, similar suggestions as to the Christian impact on Abulafia were presented, though very briefly, many years ago by Meyer H. Landauer, Yitzhak Baer, and Jacob L. Teicher. I was already acquainted with these views before 1976 and I have also added some additional proposals to them. However, these suggestions have scarcely been referenced by later scholars dealing with these issues. Those views should not only be mentioned appropriately, but also discussed in some detail, for all their strong and weak aspects, especially when scholars are dealing with exactly the same specific Christian influences on this Kabbalist. ${ }^{214}$

Obviously, not everything that happened in the past-what is called "history"should be reduced to what can now be found in extant texts. Indubitably, the reality was much richer and probably also more variegated. However, nor should history be understood as what could possibly have happened regardless of the existence of actual evidence. After all, people also spoke with each other, and we have seen above an extraordinary example of a conversation Abulafia had with Christians, but, naturally, most of these conversations are now lost. From the historical point of view, conversations between Abulafia and Franciscans or Joachimites could certainly have taken place, though for the time being, there is no evidence from Abulafia's own tes-

212 See references to my discussions of more ancient traditions concerning the angelic Yaho'el, which impacted Abulafia’s writings from 1280 onwards, in chapter 13 note 30 above.

213 Messianic Mystics, 56.

214 See above chapter 21 note 328. Baer's scant discussion of this issue should be compared to his much more elaborated and well-known analysis of the possible relations between the Zoharic literature and the Franciscans' pivotal ideal of poverty, though this more detailed analysis has also been substantially questioned by some important scholars of the Zohar, but the details of this debate do not concern us here. See Yitzhak Baer, "The Historical Background of the Ra 'aya' Meheimna" [Hebrew], Zion 5 (1940): 1-44, and the detailed critique of this hypothesis by Tishby, The Wisdom of the Zohar, 3:1438-47. 
timonies of such a conversation with these specific sorts of Christian spiritualists or of their possible imprint on his thought. After all, his report assumes his impact on his interlocutor, not the inverse.

Without seriously engaging with all the pertinent texts in their original languages or with other kinds of documents, figurative or otherwise, some of them now in print and some still in manuscript, we may become turned around, lost in a forest of wild imagination and free speculations about what could have been, grasping at one answer and neglecting the multitude of other possibilities. However, only rarely have scholars weighed those possibilities against one another, on the basis of all the possible contexts, before deciding in one way or another. This is the reason why it is difficult to find significant doubts, hesitations, or a significant resort to categories like "possible," "probable," and "plausible” in recent scholarship about Abulafia. Despite the relatively poor acquaintance with the entire extant corpus, many scholars are nevertheless confident that their proposals are indubitably correct.

The certainty of some scholars that there is a single, clear solution for the question of the sources of certain issues in Abulafia's spirituality-in this case, that he was influenced by Christian thought-is either to be envied or simply to be laughed at. Despite the fact that the Kabbalist himself does not indicate a strong Christian influence on his thought and the fact that there are scant materials, if any, that support their claims, these scholars nevertheless believe that they have the right answer. Consequently, in scholarship, there are few signs as to the possible relevance of speaking about a variety of sources from multiple places or the need to weigh between different alternatives for sources or meanings of a certain specific topic. There is no engagement with the possibility of Abulafia simply changing his mind, with what I call his conceptual fluidity. In short, the feeling I have that there is a conceptual complexity and a variety of different sources for one of the most complex thinkers in the Middle Ages is missing in much of the recent scholarship on this Kabbalist. This is the reason why no sustained efforts have been invested in order to prove which of the available sources would be more plausible than others in one specific case or another. For example, based on the analysis of the content of Abulafia's testimony, the anonymous Christian with whom Abulafia claimed to have spoken is much more likely to have been an Averroistic thinker than a Joachimist spiritualist, because of his adoption of the assumption of the existence of secrets.

Let me reiterate my position regarding some issues that were addressed in the last two appendices: the problem in scholarship, as I see it, is not with whether or not there was an impact of Christian views on Abulafia, but with questions such as what, when, how much, and, especially, whether and how this has been proven in a plausible manner. ${ }^{215}$ Without being capable of first figuring out a more compre-

215 To be sure, this does not mean that I think that there were no Christian influences on Kabbalah in general or on Abulafia's thought in particular. See, for example, some proposals for what I consider to be more reliable studies on the topic: Scholem, Origins of the Kabbalah, 422-23, 425, 428-30, 439; Gabrielle Sed-Rajna, “L'influence de Jean Scot sur la doctrine du Kabbalist Azriel de Gerone," in Jean 
hensive picture of Abulafia's thought, in particular its Islamicate background, and the sources that he explicitly mentions, and, phenomenologically speaking, without an understanding of the centrality of its profound structure concerning noetic processes, the significance and real weight of one specific theme or another in his system cannot be understood or evaluated in a balanced manner. Indeed, its meaning itself may even become distorted. Abulafia, who was born and lived almost his entire life in a variety of Christian regions and who did not know Arabic nevertheless preserves the profound structures of thought formulated in the Islamicate provinces; they informed his understanding of the traditional forms of both Judaism and Christianity.

Such a general and tentative picture should be coupled with an acquaintance with the direction of the conceptual developments over the course of two decades of Abulafia's literary career and for the three decades of his intellectual biography. Without such a general picture in mind, tentative as it may be, it is difficult for some scholars to situate some of Abulafia's more specific discussions within a larger comprehensive framework.

This essentially means that a scholar should be capable of conveying what she or he considers to be central or marginal in the wider structure of the material under scrutiny, as otherwise, the information provided may turn out to be mere descriptions of exceptions, earlier views that were marginalised, technical details, or abstract speculations that do not offer a broader or nuanced picture of the thought of a specific author or literature.

If our assumption is correct that the year 1279/80 was a significant turning point in Abulafia's intellectual career, moving him towards much more intense forms of re-

Scot Erigène et l'histoire de la philosophie (Paris: CNRS, 1977): 453-62; Shlomo Pines, "Nahmanides on Adam in the Garden of Eden in the Context of Other Interpretations of Genesis, Chapters 2 and 3" [Hebrew], in Exile and Diaspora: Studies in the History of Jewish People Presented to Prof. H. Beinart, eds. Aaron Mirsky, Avraham Grossman, and Yosef Kaplan (Ben Zvi Institute, Jerusalem, 1988): 159-64; Amos Funkenstein, “Nahmanides’ Symbolical Reading of History,” in Studies in Jewish Mysticism, eds. Joseph Dan and Frank Talmage (Cambridge, MA: Association of Jewish Studies, 1982): 129-50; Mark Sendor, "The Emergence of Provencal Kabbalah, Rabbi Isaak the Blind's Commentary on Sefer Yezir$a h$ " (PhD diss., Harvard University, 1994), 1:115-16, 377; Liebes, Studies in the Zohar, 139-61; Bar Asher, "Penance and Fasting in the Writings of Rabbi Moses de Leon," 293-319; Idel, "Sefirot above Sefirot," 246, note 41, 261, note 110, 267-68; Idel, Enchanted Chains, 190-93; Idel, "The Attitude to Christianity," and Moshe Idel, "Rabbi Israel Ba'al Shem Tov 'In the State of Walachia': Widening the Besht's Cultural Panorama," in Holy Dissent: Jewish and Christian Mystics in Eastern Europe, ed. Glenn Dynner (Detroit: Wayne State University Press, 2011):104-30. See also above, chapter 10 note 188 and Appendix D note 164. However, in my opinion, the contributions of modes of thought found in or mediated by Muslim texts, translations, and other channels of transmission to the multifaceted physiognomy of Kabbalah are incomparably more explicit, more numerous, and, in my opinion, also more profound than what can be solidly documented regarding themes found in Christianity. See, for example, Moshe Idel, "Jewish Mysticism and Muslim Mysticism" [Hebrew], Mahanayyim, n.s. 1 (1991): 28, as well as my book Hasidism: Between Ecstasy and Magic, 82-85; Idel, "Prayer, Ecstasy and Alien Thoughts in the Besht's Religious Worldview"; and, for a later summary of my approach, see my "Orienting, Orientalizing or Disorienting the Study of Kabbalah." 
demptive activity, then we may distinguish between three different decades in the activities of the ecstatic Kabbalist: 1261 to 1269, the philosophical period; 1270 to 1279 , the first phase of his Kabbalistic period, with fewer elements concerning the role played by his personality as a redemptive figure; and, finally, late 1279 to 1291, a period when the redemptive aspects of his thought, as well as the revelation of the allegedly "unknown” divine name ' $H W Y{ }^{216}$ became much more evident.

The basic conceptual vectors found in the first two stages of Abulafia's thoughtthe demythologisation of and naturalist approaches towards the classical Jewish texts, which mainly involved their philosophical allegorisation-also serve as the inner structure of his messianic or individual redemptive impulses, especially its intellectual features that were elaborated in more detail later on. Much of the content and the conceptual structure that was dominant in the first of these three periods continued to profoundly inform both the content of his writings and his reported experiences, including his conspicuous propensity towards political esotericism, in the two later periods.

This approach assumes a significant continuity in Abulafia's intellectual worldview over the years that emphasises an intelligible message, despite his adoption of letter combinations, gematria, and other of types of eccentric exegetical methods that may have led to random associative thinking that could have shattered his conceptual noetic structure (though they did not). ${ }^{217}$ Even his most incomprehensible passages are based on long, carefully calculated series of gematrias.

So far, I have not found in Abulafia's writings or in those of his disciples phenomena of glossolalia related to revelations they had, but rather a controlled type of discourse. As is evident from the different visions he describes of light, of himself (autoscopy), of letters that grow larger and larger during the experience, of the divine name, or of a cosmo-psycho-gram in the form of a globe (or a mandala, to resort to Carl G. Jung's terminology), several types of ecstatic experiences are mentioned in his writings. They most likely had a different structure from other ecstatic types such as those that generate glossolalia. Ecstasy should be seen as an umbrella term that includes many different categories, and a serious and meaningful comparison between literatures cannot be based solely on assuming an unqualified ecstatic nature, without any substantial elaboration.

In other words, in his mature life, Abulafia indubitably expanded his interests and horizons by gradually incorporating a greater awareness of eschatological issues that he understood in noetic terms. This was done without suppressing, negating, or

216 See chapter 22 note 364 above.

217 Compare, however, the quite different explanation of the content of mystical experiences as combinations of random cognitive processes by the creative unconscious in Daniel Merkur, Mystical Moments and Unitive Thinking (Albany, NY: SUNY Press, 1999). It is not an accident that Abulafia is not discussed in this book. Compare also to chapter 16 note 108 above. See also the claim of Rabbi Nathan as to the content of his revelations, as translated in Scholem, Major Trends in Jewish Mysticism, 151. 
even relegating to the margins his important initial starting points. ${ }^{218}$ Such a development is one of the major reasons for the growing complexity of his thought. Abulafia's continuous adherence to Maimonides's thought and to other aspects of the Neo-Aristotelian thought of the falāsifah generated a conceptual complexity that distinguishes him from other Kabbalists and prevents any serious sweeping or essentialist generalisations as to the nature of Kabbalah as a whole. ${ }^{219}$

\section{Appendix E: Abulafia's "The Mystery of Time” or Supra-Temporality?}

I have distinguished between secrecy and political esotericism on the one hand and mysteriology, which deals with topics that cannot be understood in an exhaustive manner, on the other. The latter is less concerned with the welfare of society and the place of the distinguished individual in it, but rather with the impenetrable secrets of the divine sphere and cosmologies replete with hidden sympathies. While the former is much more philosophically inclined, the latter is more occultist. The former is the result of the author's choice to reflect on and write or teach about issues related to those secrets or to only hint at them; the latter is much more a situation that is not necessarily chosen, but is rather an encounter, real or imagined, with the somewhat impenetrable and objective dimension of reality. My assumption is that the former type is a more useful category for understanding Abulafia, and even in the other forms of Jewish mysticism, the secrets, of whatever nature, are closer to esotericism than to mysteriology. ${ }^{1}$

218 Compare, however, Scholem, Major Trends in Jewish Mysticism, 139, where he sees Abulafia's Kabbalah as "rationalisations" of a system that is a Jewish parallel to yoga. This statement assumes an early role that was allegedly played by the mystical techniques, which are expounded in accordance with Maimonides's conceptual apparatus. However, the Kabbalist only committed the details of those techniques to writing from 1280, long after the so-called "rationalisations," whose details had been known to him from his studies described above since the early 1260s. In my opinion, the techniques were later grafted onto the earlier philosophical thought and ideals, in what I have called the profound structure, not vice versa, and there are very few attempts to interpret those techniques in a philosophical manner.

219 Compare to Wolfson's claim that he is not an essentialist in Language, Eros, Being, 88, where on the same page, he mentions "the repetition of the structure" of Kabbalah, in the singular, as well as the uncritical adoption of Franz Rosenzweig's vision of "system," again in the singular. My point in my studies is that in the vast Kabbalistic literature, there are repetitions of quite different structures, systems, or models, a fact that is obfuscated by Wolfson's resorts to generalisations such as phallocentrism or pervasive male androgyneity as characteristic of Kabbalistic literature as a whole. See also above chapter 8 note 30 and chapter 9 note 116. See also now Idel, The Privileged Divine Feminine.

1 See above in chapter 1 note 10 and chapter 5. 
In the following, I shall address some of Abulafia's texts referring to time. ${ }^{2}$ Let me deal with a secret that has recently been turned into a mystery by Elliot Wolfson, through a scholarly interpretation of a passage by Abulafia concerning a secret that has been understood as being related to "the mystery of time." I will here translate the fuller context of this passage, found in Hayyei ha-Nefeš, Abulafia's commentary on the Guide:

[a] But their issue ${ }^{3}$ is YHWH-in the world of the angels, which are the first Hawayah according to the secret of necessity, ${ }^{4} \mathrm{YHWH}-$ in the world of the spheres, which are the second Hawayah according to the secret of necessity, YHWH-in the lower world, which is the third Hawayah, the last according to the secret of necessity, those according to their degree and those according to their degree. This is the reason why the wisdom comprises all three altogether, ${ }^{5}$ those and those, and all the existent[s] of the three are [emerging] in necessary manner from the unity of God, blessed be He. However, despite this, He, blessed be He, is Unique, One alone, since in One comes the unique Hawayah, which is not so in those who are other than Him. [b] And since He does not fall under time, it is permitted to [attribute to] Him the three times equally, by saying about Him that was, and is, and will be. ${ }^{6}$ He was before man, and is together with man, and will be after man. And so the tradition is that He was before the world, and is together with the world, and will be after the world. [c] And the secret is that He was in the past, as He is now, and as He will be in the future, without change, for none of His actions changes in relation to Him and in accordance with His knowledge. All the more so as He himself does not change and inasmuch as his attributes are naught but His essence, His attributes do not change. And the

2 On time and Kabbalah in general, see my "Higher than Time," part of which has been discussed below; Moshe Idel, "Some Concepts of Time and History in Kabbalah," in Jewish History and Jewish Memory: Essays in Honor of Yosef Hayim Yerushalmi, eds. Elishiva Carlebach, John M. Efron, and David N. Myers (Hanover: Brandeis University Press, 1998): 153-88; Moshe Idel, "Sabbath: On Concepts of Time in Jewish Mysticism," in Sabbath: Idea, History, Reality, ed. Gerald Blidstein (BeerSheva: Ben-Gurion University Press, 2004): 57-93; or Idel, "Multiple Forms of Redemption" and "“The Time of the End." For medieval Kabbalah and time, see also Pedaya, Nahmanides, passim; Wolfson, "Kenotic Overflow and Temporal Transcendence"; or Adam Afterman, "Time, Eternity and Mystical Experience in Kabbalah," in Time and Eternity in Jewish Mysticism, ed. Brian Ogren (Leiden: Brill, 2015): 162-75.

3 Namely, of the three tetragrammata, mentioned beforehand, where he refers to both the Talmud and to Maimonides's Guide 1:61. See Hayyei ha-Nefeš, 72-73.

4 Hiyyuv. I am not sure that I fully understand this term. From the broader context, it may be connected to the description of God as the "Necessary Existent" in the context of the Tetragrammaton. See Ḥayyei ha-Nefeš, 73, Sitrei Torah, 75, Or ha-Śekhel, 41, Oșar 'Eden Ganuz, 1:8, 174, and above chapter 16 note 106.

5 Hokhmah $=73=H Y H, H W H, W Y H Y H=72$. The meaning of the three combinations of letters is: He was, He is, and He will be, which, when combined differently, compound three Tetragrammata or the name of twelve letters, as is specified in paragraph [b]. For the very probable source of this gematria in Abulafia's teacher Rabbi Baruch Togarmi, see Wolfson, "Kenotic Overflow and Temporal Transcendence," 189, note 208. In this passage, the term Hawayah refers to the Tetragrammaton; namely, to the threefold form of Tetragrammaton that was sometimes conceived as the Talmudic name of twelve letters, as Abulafia mentions earlier on the same page in Hayyei ha-Nefeš. See also Wolfson, "Kenotic Overflow and Temporal Transcendence," 187, note 205.

6 HYH, HWH W-YHYH. See also Or ha-Śekhel, 84. 
change that is thought by us that is found in our world is not a change in His operation, blessed be He, but [only] the revolution of the sphere. And the revolution of the sphere is not a change in the substance of the sphere, not in general and not in particular. ${ }^{7}$

I would like to first highlight what is new in paragraph [c] in comparison to his earlier discussion in the same passage about God and time, especially since the term "secret" is found there. In my opinion, the secret has to do with Abulafia's view of the immutability of the divine realm in any of the three worlds or tenses, an issue that is absent in the more traditional descriptions as he formulated in paragraph [b].

Abulafia quite emphatically refuses to allow any change in the divine essence or in His attributes, because change is related to a motion in time and God and the separate intellects are explicitly understood in this passage and elsewhere as not falling under the category of time. Such a view of the immutability of the divine realm, which includes both God and the attributes that are conceived as identical with $\mathrm{Him}$, is also found elsewhere in Abulafia's thought ${ }^{8}$ and counteracts the plausibility of the assumption made by Elliot Wolfson that the impact of human acts on the divine realm (theurgy) is a relevant category for understanding Abulafia's Kabbalah. Surprisingly enough, when dealing with the translated part of the passage from Hayyei ha-Nefeš-Wolfson did not render the last sentence of [c] into English-he has nothing to say about the flat contradiction between the view of divine immutability found in it and the concept of theurgy that he attributes to this Kabbalist. ${ }^{9}$

However, what is of particular importance here is that Abulafia conceives divine immutability (in a good Maimonidean manner) to be a secret, because, in my opinion, it contradicts the widespread biblical, Talmudic, and theosophical-theurgical images of God, which are quite dynamic. Instead, Abulafia assumes that changes take place solely in our world and depend solely on the different forms of reception

7 Ḥayyei ha-Nefeš, 72:

אבל עניינם הוא יהו"ה בעולם המלאכים שהם הויה ראשונה בסוד החיוב, יהו"ה בעולם הגלגלים שהם הויה שניה בסוד

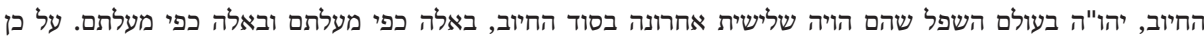

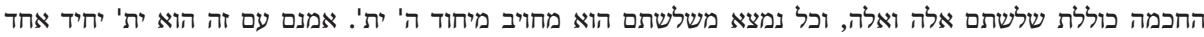

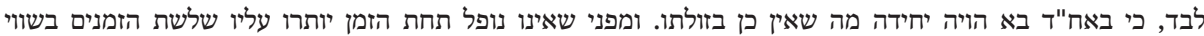

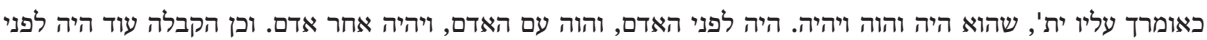

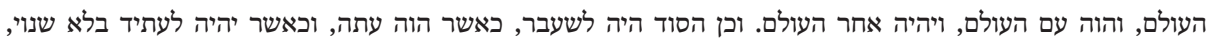

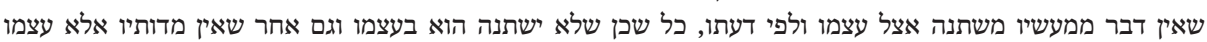

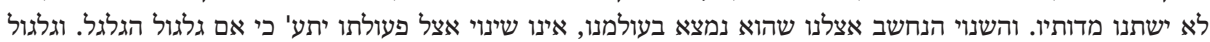

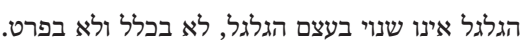

Paragraph [b] and part of [c] were translated in Wolfson, "Kenotic Overflow and Temporal Transcendence," 187. The denial of change even in the substance of the sphere, despite its motion, should be compared to a passage from Or ha-Śekhel, 29, but see Wolfson's different interpretation, "Kenotic Overflow and Temporal Transcendence," 187. See also Hayyei ha-Nefeš, 20, where Abulafia compares the union of the soul to the spiritual world as being stronger than that of the matter of the sphere to its form. For more on the issue of attributes in Abulafia, see Idel, Middot, chapter 9.

8 See, e.g., Mafteah ha-Ra'ayon, 5, Sitrei Torah, 111, and chapter 17 note 154 above.

9 "Kenotic Overflow and Temporal Transcendence," 187. See also chapter 17 note 146 above. 
of the powers from above by the human recipients. Thus, no mystery is intended here.

Another secret is the presence of a Tetragrammaton in each of the three worlds, as mentioned in paragraph [a], which may be understood as being connected to the presence of an immutable entity within growingly mutable worlds. This is also a Maimonidean position since it fits the Great Eagle's assumption as to the naturalness of the divine presence in the world, hinted in paragraph [b] by the "togetherness" of the divine within the three worlds, ${ }^{10}$ a view that I have described as "limited pantheism." 11 In any case, what is paramount for my argument is the fact that Abulafia regarded the act of cognition as taking place outside of time. ${ }^{12}$

Therefore, in the passage above, there is no "mystery of time" as has been claimed, ${ }^{13}$ just as there is no "personification of time" by the figure of the angel Metatron in another passage that has been quoted from one of Abulafia's books. In fact, the quoted passage has nothing to do with Metatron, explicitly or implicitly, and very little to do with time, as is evident from even a superficial reading of its wider context. I see no need to further prove my assessment. ${ }^{14}$

Let me turn to an analysis of Abulafia's approach to time and its experience as I understand it. I will first translate a neglected passage from his Commentary on Sefer Yeșirah, where he writes that the transcendence of time is required and portrays it neither as an experience that takes place in time nor as a personification. When describing humans, Abulafia writes:

We are the very last of all the existents, and from this side, we are at the extreme distance from Him. And because we are the furthest beings [remote] from him, He desired that we should be extremely close to Him from another side, and He saw that there was no manner that is more excellent than that in which He created us, and He set us as bodies that possess faculties [kohot] that receive from others [the] hawayyot that exist for short times, and there are hawayyot that are present without time at all and they are the eternal [hawayyot]. And everything that is universal is eternal, and everything that is eternal is universal, and she/he will not be called innovated or created, but by an equivocal name. ${ }^{15}$

10 See my "Deus sive Natura," 185-86.

11 See chapter 21 note 305 above.

12 See his Oșar 'Eden Ganuz, 124, Sefer ha-Hešeq, 80, and Rabbi Nathan ben Sa'adyah Ḥar'ar, Le Porte della Giustizia, 476.

13 Compare to Wolfson, "Kenotic Overflow and Temporal Transcendence," 187. This does not mean that elsewhere there is no "secret of time" (סוד הזמן) in Abulafia's writings. See Sitrei Torah, 122, Mafteah ha-Sefirot, 20, and Hayyei ha- 'Olam ha-Ba', but this issue deserves a separate study that will deal with the complex question of his cosmology. See chapter 19 note 219 above.

14 Wolfson, "Kenotic Overflow and Temporal Transcendence," 190, note 211, where he interprets a passage from Imrei Šefer, 34.

15 Commentary on Sefer Yeșirah, 19:

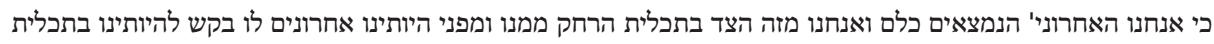

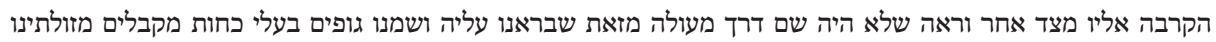

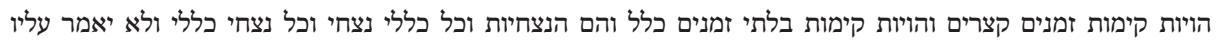


According to this passage, God demands that humans become eternal by turning from a particular or individual into a universal entity, ${ }^{16}$ a metanoic experience that is predicated on receiving eternal or temporary powers, referenced by the enigmatic term hawayyot, from the outside. Though such a reception causes a change in the individual, it is not a change insofar as the eternal hawayyot are concerned.

Abulafia distinguishes between the particular type of experience related to the body and the lower faculties in man, which are extremely remote from the divinity, and the spiritual experience related to the other faculties, which may bring someone closer to, or, according to another passage to be discussed immediately below, within God. I assume that the term hawayyot refers to separate intellects or perhaps even higher entities or forms of ideas within the divine mind. ${ }^{17}$ The onus of the change is here put on the human constitution, which can receive different influences because of its composite and changing nature. We may assume that the body receives the temporary influences while the spirit, or the higher faculties, receive the spiritual ones. It is important to note that the above statement covers humans in general and not just the Jews. Therefore, this amounts to a more universalist approach, which is indeed Abulafia's main approach, as we have seen above.

This transformation from a particular individual into a general or universal being is certainly not new in Abulafia and his school, as they were following some brief discussions by Abraham ibn Ezra. ${ }^{18}$ Let me point out that this passage is somewhat reminiscent of Meister Eckhart's statement in his commentary on Psalm 86: "We have been put into time for the purpose of coming nearer to and becoming like God through rational activity in time," ${ }^{19}$ though Abulafia would not have accepted this view as it attributes importance to time.

A similar position to what we saw in the last quote is found in another treatise, Sefer Ner Elohim, which belongs to ecstatic Kabbalah and was not authored by Abulafia himself:

Compare also to the similar views on general principles in Al-Bațalyawsì's Sefer ha-'Aggulot haRa'ayoniyyot, ed. D. Kaufmann (Budapest: s.n., 1880), 50. On general principles, see also Or haŚekhel, 40, 108-9, and chapter 21 note 251 above. For an interesting discussion that complements the translated passage, found in the same book, immediately afterwards on page 20, see chapter 21 note 300 above.

16 See chapter 21 above and my "Universalization and Integration."

17 See Sitrei Torah, Ms. Paris, BN 774, fol. 148b, 116. For more on this passage, see Idel, "Sefirot above Sefirot," 260-61, and compare Wolfson, "Kenotic Overflow and Temporal Transcendence," 186. See also Imrei Šefer, 129.

18 As judiciously pointed out by Weinstock in his footnotes to his edition of Abulafia's Commentary on Sefer Yeșirah, 19.

19 Cf. Bernard McGinn, The Harvest of Mysticism in Medieval Germany (New York: Herder \& Herder, 2005), 192. 
The root of all the negative commandments alludes to not following the temporary matters, since whoever is drawn towards the vanities of temporality, ${ }^{20}$ his soul shall survive in the vanities of temporality; and whoever is drawn towards God, who is above temporality [le-ma lah meha-zeman], his soul shall survive in eternity, beyond time [be-lo' zeman], within God, may He be blessed. ${ }^{21}$

Following a principle formulated in Abulafia's thought on this issue, ${ }^{22}$ the anonymous Kabbalist describes the effect of a person's union according to the object to which she/he chooses to adhere: if one adheres to temporary entities, one's survival depends on time and is transient; but if one does so to an eternal entity, then the survival will be eternal too.

Interestingly, the eternal is here described as God and as being beyond time; adherence means here an entrance into the divine realm. God is described using the Hebrew phrase le-ma lah me-ha-zeman, an expression that was rare in the Middle Ages but which some centuries later became a leitmotif in the major school of East European Hasidism. ${ }^{23}$ For the time being, it seems that this is the first dated occurrence of this phrase in Jewish literature, though it is most probably not the first source or the origin of any influence on other thinkers, as the anonymous book was only preserved in a single unique manuscript and was, to the best of my knowledge, never quoted by any Kabbalist. The soul's experience is, however, described by a slightly different phrase: beli zeman, "without time." This divergence may refer to a status achieved by the soul after leaving time. I wonder whether the expression "within" that is related to God reflects some act of transcending space, just as time was imagined to be transcended, or, alternatively, as comprising all the space just as time was conceived to be comprised.

If Abulafia's highest experience is described as a profound transformation that affects the human intellect and transcends time and space, I also assume the plau-

20 Hevlei ha-zeman. This warning as to the negativity and the futilities of time is a topos in the Jewish Middle Ages. It recurs in Spanish Jewish poetry, and was shared by several Jewish thinkers, especially Maimonides. See, for example, the material assembled in Israel Levin, "Zeman and Tevel in the Hebrew Secular Poetry in Spain in the Middle Ages” [Hebrew], Oșar Yehudei Sefarad 5 (1962): 68-79; Maimonides's Mishneh Torah, Hilekhot Yesodei ha-Torah, chapter 7, halakhah 1, or ibn Falaquera, Sefer ha-Ma'alot, 50. For Abulafia's recurrent use of this phrase see, for example, Or ha-Śekhel, 20, 21, 105; Oșar 'Eden Ganuz, 331; Mafteah ha-Tokhahot, 62; or Imrei Šefer, 136. For other negative contexts of using zeman, sometime referring to the mahshakh ha-zeman, "the darkness of time," see his Or ha-Śekhel, 3; Sitrei Torah, 113, 137, 170; Oșar 'Eden Ganuz, 371.

21 Sefer Ner Elohim, Ms. Munich, 10, fol. 154b, 68:

והשרש של מצוות לא תעשה כולן הוא לרמוז לבלתי לכת אחרי העניינים הזמניים. כי כל הנמשך אחר הבלי הזמן השארות

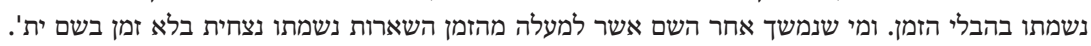

This text is especially close to Or ha-Śekhel, 21. This vision of the negative commandments as an allusion-namely, as preventing someone from being immersed in mundane issues-deserves a separate discussion. See chapter 10 note 182 above.

22 See the passage from Oșar 'Eden Ganuz, translated in my The Mystical Experience, 124-25.

23 See my "Higher Than Time." 
sibility of the cessation of ritual and social life for as long as the supra-temporal experience is imagined to last. The intellectualistic nature of the transformation and the union is well-chosen in an anonymous text that I attribute to Abulafia: "From the side of his knowledge the one that comprehends it will become a separate intellect, and this is the reason for his survival, that is the best that it is possible to achieve." ${ }^{24}$ The perfect human's acquired supra-temporal existence is one of the reasons why the ritual is conceived as secondary or irrelevant in the ideal state of the mystic.

In short, instead of assuming the hypostatic vision of time or its personification in the Agent Intellect in ecstatic Kabbalah, as proposed by Wolfson, my assumption is that Abulafia was concerned with the ideal attainment of an experience of transcending time, since time was a category he understood in an Aristotelian manner as being inseparably connected to motion. ${ }^{25}$ He was pre-eminently concerned with attaining the highest possible experience in order to be able to intelligise as the separate cosmic intellects do, an attainment that amounts to becoming universal and thus trans-temporal and leads to possessing some form of unity that resembles the unity of the divinity, in a manner reminiscent of Neo-Platonic views. ${ }^{26}$ Indeed, another plausible source for the syntagm "higher than time" is the famous Neo-Platonic treatise known as Liber de Causis, which Abulafia knew, ${ }^{27}$ and excerpts of it are found together with Abulafian material in manuscripts, which requires additional studies. $^{28}$

24 See chapter 21 note 289 above.

25 See, e.g., Sefer ha-Melammed, 9; Sitrei Torah, 115-16; and Imrei Šefer, 127, 129.

26 Ahdut. See, for example, Hayyei ha-Nefeš, 20, and Or ha-Śekhel, 41. For the nexus between this term and an experience considered to be higher than time in the various passages found in the traditions of the Hasidic master known as the Great Maggid and his school, see my "Higher Than Time," 197-208.

27 See his Imrei Šefer, 193-94, and Idel, "The Magical and Neoplatonic Interpretations of Kabbalah in the Renaissance," 216-17, 220-23; Idel, "Jewish Kabbalah and Platonism in the Middle Ages and Renaissance," 332-33.

28 A discussion of hypostatic time from chapter 2 of this book is found together with Abulafian material in manuscripts. See my "Higher Than Time," 186 and note 21. See, e.g., Ms Paris BN, 776, fols. 192b-193a. 